OPEN ACCESS

Edited by:

Inaki Hormaza,

Institute of Subtropical and Mediterranean Horticulture

La Mayora, Spain

Reviewed by:

Ryutaro Tao,

Kyoto University, Japan

Ana Wünsch,

Aragon Agrifood Research and Technology Center (CITA), Spain

*Correspondence:

Carlos Romero

cromero@ibmcp.upv.es

Specialty section:

This article was submitted to

Plant Breeding,

a section of the journal

Frontiers in Plant Science

Received: 20 November 2019

Accepted: 10 February 2020

Published: 19 March 2020

Citation:

Muñoz-Sanz JV, Zuriaga E, Cruz-García F, McClure B and Romero C (2020) Self-(In)compatibility

Systems: Target Traits for

Crop-Production, Plant Breeding, and Biotechnology.

Front. Plant Sci. 11:195.

doi: $10.3389 /$ fpls.2020.00195

\section{Self-(In)compatibility Systems: Target Traits for Crop-Production, Plant Breeding, and Biotechnology}

\author{
Juan Vicente Muñoz-Sanz ${ }^{1}$, Elena Zuriaga ${ }^{2}$, Felipe Cruz-Garcia ${ }^{3}$, Bruce McClure ${ }^{1}$ \\ and Carlos Romero ${ }^{4 *}$ \\ ${ }^{1}$ Department of Biochemistry, University of Missouri, Columbia, MO, United States, ${ }^{2}$ Centro de Citricultura y Producción Vegetal, \\ Instituto Valenciano de Investigaciones Agrarias (MIA), Valencia, Spain, ${ }^{3}$ Departmento de Bioquímica, Facultad de Química, \\ Universidad Nacional Autonoma de Mexico, Mexico City, Mexico, ${ }^{4}$ Instituto de Biología Molecular y Celular de Plantas (IBMCP), \\ Consejo Superior de Investigaciones Cientificas (CSIC) - Universitat Politécnica de València (UPV), Valencia, Spain
}

Self-incompatibility (SI) mechanisms prevent self-fertilization in flowering plants based on specific discrimination between self- and non-self pollen. Since this trait promotes outcrossing and avoids inbreeding it is a widespread mechanism of controlling sexual plant reproduction. Growers and breeders have effectively exploited SI as a tool for manipulating domesticated crops for thousands of years. However, only within the past thirty years have studies begun to elucidate the underlying molecular features of SI. The specific S-determinants and some modifier factors controlling SI have been identified in the sporophytic system exhibited by Brassica species and in the two very distinct gametophytic systems present in Papaveraceae on one side and in Solanaceae, Rosaceae, and Plantaginaceae on the other. Molecular level studies have enabled SI to SC transitions (and vice versa) to be intentionally manipulated using marker assisted breeding and targeted approaches based on transgene integration, silencing, and more recently CRISPR knock-out of SI-related factors. These scientific advances have, in turn, provided a solid basis to implement new crop production and plant breeding practices. Applications of self-(in)compatibility include widely differing objectives such as crop yield and quality improvement, marker-assisted breeding through SI genotyping, and development of hybrids for overcoming intra- and interspecific reproductive barriers. Here, we review scientific progress as well as patented applications of SI, and also highlight future prospects including further elucidation of SI systems, deepening our understanding of SI-environment relationships, and new perspectives on plant self/non-self recognition.

Keywords: self-(in)compatibility, S-genotyping, interspecific reproductive barriers, hybrid breeding, crop production, plant breeding

\footnotetext{
Abbreviations: ARC1, Arm Repeat Containing 1 U-box type E3-ligase; CUL1, Pollen-expressed Cullin1 gene; GSI, Gametophytic Self-Incompatibility; IRB, Interspecific Reproductive Barriers; LSI, Late acting Self-Incompatibility; MLPK, M-Locus Protein Kinase; ParMDO, Prunus armeniaca M-locus Disulfide Bond A-like Oxidoreductase; PCD, Programmed Cell Death; SSK1, SLF-interacting-SKP1-like gene; PSC, Pseudo-Self-Compatibility; RNAi, RNA interference; SC, SelfCompatibility/Self-Compatible; SCR/SP11, Slocus Cysteine-Rich protein; SI, Self-Incompatibility/Self-Incompatible; SKP, Suppressor of Kinetochore Protein; SLF/SFB, S-Locus F-box proteins; SLG, S-Locus Glycoprotein; Sli, S-locus inhibitor gene; SRK, S-locus serine/threonine Receptor Kinase; SSI, Sporophytic Self-Incompatibility; UI, Unilateral Incompatibility.
} 


\section{INTRODUCTION}

\section{Early Background on Self-Incompatibility}

Humans have been aware of the link between pollination and seed production since the Neolithic period, as reflected by the laws of Hammurabi (1750 B.C.E.), these being integral parts of agriculture development (Weiss, 2015). This basic knowledge is represented in several Assyrian reliefs dating to the reign of Ashurnasirpal II (884-859 B.C.E.) that show gods and priests performing fertilization rituals of date palms (Weiss, 2015). While people have been benefitting from sexual reproduction for thousands of years, the male and female plant reproductive organs were not explicitly documented until the publication of Rudolf Jakob Camerarius's "De sexu Plantarum epistole" in 1694 (Abrol, 2012). In 1764, Joseph Gottlieb Kölreuter reported the occurrence of self-sterility and performed cross-pollinations to obtain interspecific hybrids in Verbascum (East and Park, 1917). A century later, Charles Darwin established the influence of selfincompatibility (SI) in plants in his works, The effects of cross and self-fertilization in the vegetable kingdom (1876) and The different forms of flowers on plants of the same species (1877) (McClure, 2009).

Botanists subsequently demonstrated, in Reseda and Nicotiana, that self-sterility follows Mendelian inheritance (East and Park, 1917). The S-locus and its multi-allelic nature were then shown to genetically control self-sterility in Nicotiana, leading to intrasterile and interfertile compatibility classes (East and Yarnell, 1929). In light of these findings, the term "selfsterility" was progressively replaced with the term "selfincompatibility" (McClure, 2009). By then, breeders from both public institutions and private companies focused interest on SI as a tool. The John Innes Horticultural Institution has been studying incompatibility and sterility in plums, cherries, and apples since 1911, and in pears since the 1930s (Crane and Lewis, 1942). For instance, cross-pollinations were used to define intercompatible groups in sweet cherry (Prunus avium L.) cultivars (Crane and Brown, 1937), and afterwards a pollen irradiation program produced the first self-compatible (SC) cultivars within this strictly SI species (Lewis and Crowe, 1954). In 1940, Sakata Seed Company introduced the $F_{1^{-}}$ hybrid cabbage cv. Suteni Kanran, produced using SI. This success was soon followed by Takii \& Co. Ltd's introduction of the cabbage (Brassica oleracea L.) cvs. Choko-1c and Choko-1cc in 1950 (Watanabe et al., 2008).

Early commercial interest in SI was not restricted to fruit trees (Rosaceae) and cabbages (Brassicaceae). It extended to other crop species, including potato (Solanum tuberosum L.), sunflower (Helianthus annuus L.), rye (Secale cereale [L.] M. Bieb.), cocoa (Theobroma cacao L.), and pummelo (Citrus grandis Osbeck) [see De Nettancourt (2001) for a full review of the early works on SI in a broad range of species].

The underlying molecular basis for SI remained a black box until the mid-1980s. Subsequent discoveries have generated new avenues for manipulating SI to the benefit of crop production and plant breeding. To date, consistent evidence identifying the molecular determinants of SI is available in Brassicaceae, Rosaceae, Solanaceae, Plantaginaceae, Rubiaceae, and
Papaveraceae, although a plethora of studies are underway in additional species.

\section{Molecular Mechanisms of SI}

Recent reviews of SI mechanisms provide detailed descriptions of molecular and genetic mechanisms (McClure et al., 2011; Iwano and Takayama, 2012; Wilkins et al., 2014; Fujii et al., 2016; Bedinger et al., 2017; Sehgal and Singh, 2018; Wang et al., 2018). Here, we provide an overview sufficient for discussing aspects relevant to crop breeding and production. SI prevents selffertilization based on the discrimination between self- and non-self pollen. It has been reported in more than 100 plant families and occurs in approximately $40 \%$ of species (Igic et al., 2008) including many important crops (e.g., canola, potato, pome and stone fruits, olive, cocoa, tea, coffee, etc.) and/or their wild relatives. In many angiosperms, SI is genetically controlled by a single multiallelic locus, termed the $S$-locus, though systems controlled by two (or more) loci have also been described in certain species (e.g. grasses) (De Nettancourt, 2001). The $S$-locus encodes both male and female specificity determinants ( $S$-determinants) whose products are predicted to interact and trigger the self/non-self discrimination process (Iwano and Takayama, 2012). Most types of SI can be classified as sporophytic or gametophytic based on time of gene action in the stamen (De Nettancourt, 2001). The pollen phenotype is determined by the $S$-genotype of the diploid pollen-parent in sporophytic SI and by the genotype of the individual microspore in gametophytic SI. Three SI mechanisms have been characterized at the molecular level. Sporophytic self-incompatibility (SSI) has been elucidated in Brassicaceae, and two distinct types of gametophytic selfincompatibility (GSI) have been extensively studied, S-RNasebased SI in Solanaceae and Rosaceae, and the Papaver system based on programmed cell death (PCD).

In Brassicaceae, $S$-locus genes encode serine/threonine receptor kinase (SRK) (Takasaki et al., 2000) and cysteine-rich (SP11/SCR) proteins (Schopfer et al., 1999) that, respectively, form the female and male $S$-determinants. Both $S$-locus genes, and a third gene encoding a glycoprotein $(S L G)$ that may enhance SI expression (Takasaki et al., 2000), are tightly linked and inherited as an S-haplotype (Sehgal and Singh, 2018). SRK protein is localized to the plasma membrane of the papilla stigmatic cells, and the small SP11 polypeptide is secreted from the anther tapetum, deposited onto the pollen coat, and finally acts as an SRK ligand upon pollination (Iwano and Takayama, 2012). Many Brassicaceae S-haplotypes have been identified. They exhibit complex hierarchical dominance relationships that are controlled by polymorphic small RNAs and their targets (Yasuda et al., 2016). It should be noted that these dominance relationships complicate the observed compatibility patterns and are, thus, of considerable practical importance. However, in uncomplicated examples, specific interaction between SP11 and SRK from the same S-haplotype triggers the self-pollen rejection mechanism in the stigma papillar cell. Downstream events are controlled by additional factors. The M-locus protein kinase (MLPK) interacts with SRK to transduce SI signaling and an arm repeat containing 1 U-box type E3-ligase 
(ARC1) ubiquitinates and degrades the Exo70A1 factor required for pollen growth. On the contrary, other factors such as the thioredoxin h-like 1 (THL1) and the kinase-associated protein phosphatase (KAPP) inhibit SRK and act as negative regulators of the SI response (Cabrillac et al., 2001). The interaction between SRK and SP11 has also been shown to lead to an increase in cytosolic $\left[\mathrm{Ca}^{2+}\right]$ in the papilla cell but how this calcium influx prevents self-pollen growth is unclear (Iwano et al., 2015).

S-RNase based GSI is present in widely divergent families (i.e., Rosaceae, Solanaceae, Scrophulariaceae, Rubiaceae). Surprisingly, although different taxa use similar genes to determine the specificity of pollen rejection, the detailed mechanisms show important differences. Nevertheless, in across all families, the $S$-locus contains at least two linked genes (although often many more). In every case, one gene encodes pistil-expressed glycoproteins with ribonuclease activity (S-RNases) that act as highly selective cytotoxins that cause rejection of pollen when its single $S$-haplotype matches either of the two S-haplotypes in the diploid pistil (McClure et al., 1989; Boskovic and Tobutt, 1996; Xue et al., 1996). The other is an Fbox protein gene specifically expressed in pollen, termed $S L F$ or $S F B$, depending on the family. Importantly, $S$-haplotypes in Solanaceae and in the Rosaceae tribe Maleae (apple, pear) have an array of 16 to 20 SLF genes that collectively contribute to pollen SI functions (Kubo et al., 2010; Kakui et al., 2011; Williams et al., 2014). In contrast pollen-side function in SI Prunus species (Rosaceae) is provided by a single SFB gene (Ushijima et al., 2004; Sonneveld et al., 2005). The F-box protein gene was first identified in Antirrhinum (Lai et al., 2002) and later in Prunus (Entani et al., 2003; Ushijima et al., 2003) and Petunia (Sijacic et al., 2004). F-box proteins are best known for their roles in the $26 \mathrm{~S}$ ubiquitin/proteasome pathway (by forming the SCF complex along with SKP1 and Cullin1 proteins) and the reported interaction between the $\mathrm{AhSLF}_{2} \mathrm{~F}$ box protein and self/cross S-RNases in Antirrhinum pollen suggested that cross $\mathrm{S}$-RNases might be inactivated through this pathway (Qiao et al., 2004). These and other findings support a model where non-self S-RNases are degraded in compatible pollinations, but in self-pollinations self S-RNases evade degradation and degrade the pollen RNA. In Solanaceae, ubiquitation and degradation of S-RNase is attributed to the collective action of the array of 16 to 20 SLF proteins (Kubo et al., 2010), but self-S-RNase is not degraded because it fails to be recognized (Kubo et al., 2015). This is referred to as the collaborative non-self recognition model (i.e., the array of SLF proteins recognizes non-self S-RNase) and it is currently the most widely accepted model. However, S-RNases are also sequestered in the pollen tube endomembrane system and this may also contribute to compatibility (Goldraij et al., 2006). Remarkably, knock-out mutations in Prunus SFB genes confer SC at odds with the collaborative non-self recognition model prediction. Thus, an alternative model has been suggested in Prunus where self-SFB protects self-S-RNases from a "general inhibitor" (proposed to be the S-locus linked SLF-like2 factor) that detoxifies all self/nonself-S-RNases (Matsumoto and Tao,
2016). Also, the collaborative non-self recognition model only addresses the roles of S-RNase and SLF proteins and there is compelling evidence that pistil factors (modifiers) that do not contribute to $S$-specificity are nevertheless required for SI in Solanaceae, including HT-B (McClure et al., 1999), $120 \mathrm{kDa}$ glycoprotein (Hancock et al., 2005), the thioredoxin NaTrxh (Juárez-Díaz et al., 2006), the proteinase inhibitor NaStEP (Busot et al., 2008), and the mitochondrial phosphate carrier NaSIPP (García-Valencia et al., 2017). Moreover, pollen modifiers have been identified in Rosaceae including an ATP-Binding Cassette F-protein (ABCF) transporter in Malus (Meng et al., 2014) as well as the Prunus armeniaca M-locus disulfide bond A-like oxidoreductase (ParMDO) (Muñoz-Sanz et al., 2017a) and the $P$. avium M-locus glutathione S-transferase (MGST) (Ono et al., 2018). Clearly, although enormous progress has been made, much remains to be learned about S-RNase-based SI.

The physiology of GSI in poppy (Papaver rhoeas L.) has been elucidated more fully than any other system. The $S$-locus comprises two tightly linked genes that encode the female (PrsS) and male (PrpS) S-determinants. PrsS is a small, highly polymorphic protein secreted by stigmatic papilla cells (Foote et al., 1994) that acts as a signaling ligand to interact with the pollen-expressed transmembrane protein PrpS (Wheeler et al., 2009).The selfinteraction triggers a range of responses, including an increase in cytosolic free $\mathrm{Ca}^{2+}$, an influx of $\mathrm{Ca}^{2+}$ and $\mathrm{K}^{+}$, and the production of reactive oxygen species (ROS) and nitric oxide. These processes, in turn, act on downstream targets. The soluble organic pyrophosphatase p26 and the MAP Kinase p56 are rapidly phosphorylated while the actin cytoskeleton is progressively depolymerized leading to PCD. DNA fragmentation and a caspase-like activity, other hallmarks of PCD, are also detected (Wilkins et al., 2014). SI-induced acidification of the pollen tube cytosol has also recently been identified as a trigger for PCD. Reduced cytosolic pH signals to the SI-induced caspase3-like activity, reduction of the p26 pyrophosphatase activity, formation of filamentous actin (F-actin) foci, and their colocalization with certain actin binding proteins, but further exploration is still warrented (Wang et al., 2018).

\section{APPLICATIONS TO CROP PRODUCTION AND BREEDING}

Our increasing understanding of the molecular basis of SI is providing new opportunities to exploit this trait for crop improvement by breeding and biotechnology-based approaches. Applications derived from current knowledge on SI are diverse but can be grouped into three main categories: crop production (yield and quality), marker-assisted breeding, and hybrid development (intra- and interspecific).

\section{SI Versus SC in Crop Production, Yield, and Quality \\ Pollenizers and Orchard Management}

In crops exhibiting SI (and even in SC crops), cultivars that serve as pollen donors ("pollenizers") are usually interspersed 
throughout orchards since fruit set depends largely on crosspollinations. Pollenizers are commonly used in canola (Brassica napus L.), sunflower, strawberry (Fragaria $\mathrm{x}$ anannasa [Weston] Duchesne), and fruit trees such as apple (Malus $x$ domestica L.), European pear (Pyrus communis), sweet cherry, Japanese plum (Prunus salicina Lindl), etc. (Woodcock, 2012). The use of pollenizers is also recommended in olive (Olea europaea L.) where the recent discovery of homomorphic sporophytic diallelic SI (DSI) should facilitate their selection (Saumitou-Laprade et al., 2017).

In diploid fruit tree species that display GSI, outcrosses are classified into three types: incompatible (parents share both $S$ haplotypes), semi-compatible (one shared $S$-haplotype), and fully compatible (no shared $S$-haplotype). In semi-compatible crosses, half the available pollen grains are rejected, which may have a significant impact on fruit set and yield (fruit size), for instance, in apple, European pears, and Japanese plums when grown in sub-optimal regions (e.g., the Mediterranean basin) (Schneider et al., 2005; Zisovich et al., 2005; Sapir et al., 2008). When honeybee visits are boosted, semi-compatible cultivars show increased yields, confirming that lack of compatible pollen is responsible for yield reduction (Stern et al., 2001; Stern et al., 2004; Sapir et al., 2007). In addition, in genera with many ovules such as Malus and Pyrus, a reduction in fertilization may result in fewer seeds and inferior fruit quality. In these and other species, SC is linked to satisfactory fruit set, superior yields, or even overcropping (Goldway et al., 2007; Claessen et al., 2019). SC may also be desirable because it obviates the need for pollenizers (relying on bloom overlapping) and, thus, allows a single cultivar to be grown in a "solid block" to produce a more uniform crop. SC also has been considered to offset the effects of colony collapse disorder on honeybee pollination (e.g., in the California almond industry). However, while SC may reduce the number of hives required, it cannot always guarantee full yields, as some crops require cross-pollination for maximum fruit set (e.g., sunflower, canola, sour cherry [Prunus cerasus L.], almond [Prunus dulcis \{Mill.\} D.A.Webb.], apricot [Prunus armeniaca L.], etc.). For instance, some SC apple and pear varieties, where SC may be associated with defective expression of the $S$-RNase, show low fruit set, but fruit set is restored (and displaces self-pollination) if cross-pollen is available (Schneider et al., 2001; Zhang and Hiratsuka, 2005). In addition, SC is not always sufficient for self-fruitfulness since insects may be needed for effective selfpollination because of the flower structure. Conversely, honeybee pollination may induce over-pollination in SC stone fruits (i.e., sour cherry, apricot, peach [Prunus persica \{L.\} Batsch]) leading to overly heavy fruit set and undersized fruits of reduced value (Woodcock, 2012). Also, this may eventually occur with SI cultivars. Thus, fruit set is not only SI/SC phenotype dependent but also cultivar dependent.

\section{Different Sources of SC: A Favorable Trait for Yield Enhancement}

In otherwise SI crops, most commercial SC cultivars derive from spontaneous and induced style- or pollen-part mutations identified and selected by growers and breeders (Figure 1A).
These mutations are continually being characterized at the molecular level but use of uncharacterized sources of SC remains common. In stone fruits (Prunus), such as apricot, Japanese apricot (Prunus mume Sieb. Et Zucc.), Japanese plum, or almond, SC is usually linked to a particular self-fertility $S$ locus allele (i.e., $S_{\mathrm{C}}, S^{\mathrm{f}}, S_{\mathrm{e}}$, and $S_{\mathrm{f}}$, respectively) (Yamane and Tao, 2009). Prunus SC alleles with loss-of-function S-RNase mutations are known, but $S F B$ mutations are more common (Yamane and Tao, 2009). For example, in the 1940s the John Innes Center sweet cherry breeding program used pollen x-ray irradiation to induce SC in 'Napoleon.' A number of SC commercial cultivars derived from 'Napoleon,' including 'Stella,' 'Lapins,' 'Newstar,' and 'Sweethart' were thus obtained. Much later, all these SC cultivars were shown to possess a common defective (mutated) $S F B^{4^{\prime}}$ allele (Ushijima et al., 2004; Sonneveld et al., 2005). In apricot cultivars, SC is mainly conferred by the mutant $S F B_{\mathrm{C}}$ allele, but an unlinked mutation at the M-locus ParMDO gene represents another source of SC in varieties such as 'Canino,' 'Patterson,' 'Trevatt,' and 'Portici' (Muñoz-Sanz et al., 2017a; Muñoz-Sanz et al., 2017b). Similarly a mutation at the M-locus GST gene confers SC in the sweet cherry cultivar 'Cristobalina' (Wunsch and Hormaza, 2004; Ono et al., 2018). In another example, SC turnip (Brassica rapa L.) cultivars 'Yellow Sarson' and 'Dahuangyoucai' carry indels affecting SRK and SP11 as well as a knockout point mutation in the non-S-locus gene MLPK (Zhang et al., 2013).

Knowledge of the molecular and genetic basis of SI has enabled SC to be engineered in a targeted manner (Figure 1B). Shiba et al. (1995) were the first to successfully use a targeted strategy to overcome SI. They obtained SC Brassica rapa by suppressing SLG expression, and most likely $S R K$ expression as well due to their high sequence similarity, using an antisense SLG construct. Using a similar approach, Stone et al. (1999) produced SC to the otherwise SI Brassica napus cv. W1 by introducing an antisense ARC1 cDNA. Much later, Jung et al. (2012) developed SC B. rapa using RNAimediated $S$-locus gene silencing. This RNAi construct was prepared from the $S_{60}$-allele of the pollen $S$-determinant, SP11/SCR (cv. 'Osome'). Transgenic RNAi lines were shown to be stable and highly SC (Figure 1B). Transfer of this engineered SC into the commercial SI variety 'Seoulbechhu' demonstrates the utility of this approach for breeding. In pome fruits Broothaerts et al. (2004) developed a self-fertile apple cultivar (US Patent No 20060123514) by silencing $S$ - $R$ Nase gene expression in SI cv. 'Elstar' ( $S_{3} S_{5}$ genotype) (Figure 1B). They described two independent transgenic trees expressing an $S_{3}$-RNase antisense construct. These trees showed normal pollen tube growth and fertilization after selfing and produced normal levels of fruits and seeds. Interestingly, both $S_{3}$ and $S_{5}$-RNases were silenced, presumably because of sequence similarity. SC was retained in these trees over several years without obvious adverse effects. Much more recently, CRISPR-induced knockouts of S-RNase have been used to generate SC diploid lines for breeding purposes in potato (Solanum tuberosum L.) (Ye et al., 2018; Enciso-Rodriguez et al., 2019) (Figure 1B).

\section{Instances Where SI is Preferred for Crop Production}

When the absence of seed or fertilization is desirable SI may be the preferred condition. For instance, seedless fruits are highly 

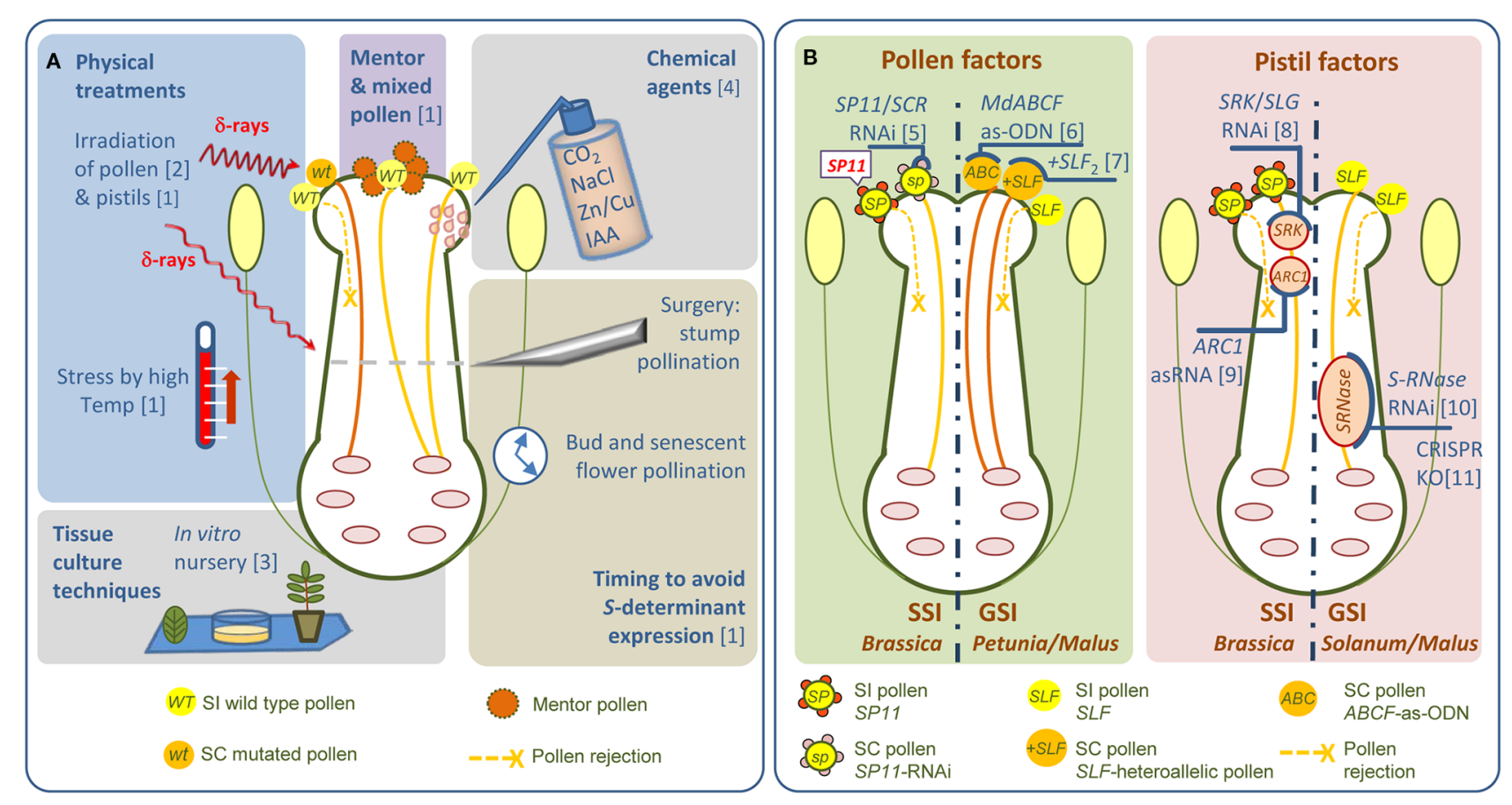

FIGURE 1 | Untargeted and molecular-targeted strategies for overcoming SI. (A) The most common types of untargeted strategies to overcome SI are shown. (B) Molecularbased strategies in crop species exhibiting the SSI and GSI systems. Strategies to down-regulate pollen- and pistil-expressed genes by RNAi/as-ODN/as-RNA or CRISPR. RNAi, RNA interference; as-ODN, antisense-oligodeoxynucleotide; asRNA, antisense RNA. References: [1] De Nettancourt (2001); [2] Lewis and Crowe (1954); [3] De La Fuente et al. (2013); [4] Kučera et al. (2006); [5] Jung et al. (2012); [6] Meng et al. (2014); [7] Sijacic et al. (2004); [8] Shiba et al. (1995); [9] Stone et al. (1999); [10] Broothaerts et al. (2004); [11] Ye et al. (2018).

desirable in some crops such as citrus (e.g., orange, mandarin, lemon, etc.). Most citrus cultivars display some degree of parthenocarpy and, thus, they form normal, but seedless, fruits without fertilization. However, when otherwise seedless cultivars are cultivated in proximity of cross-compatible cultivars undesirable seeded fruits may still be formed. Consequently, SI is regarded as a target trait for Citrus breeding so that it could be used in conjunction with parthenocarpy to greatly reduce seed number (Vardi et al., 2008). This approach was validated with a mutant mandarin (Citrus reticulata Blanco) cv. 'Wuzishatangju' where seedlessness could be attributed to GSI (Ye et al., 2009). Furthermore, roles for GSI in seedlessness also have been reported in the mandarin cv. 'Afourer' (Gambetta et al., 2013) and in the lemon (Citrus limon [L.] Burm. F.) cultivars 'Xiangshui' (Zhang et al., 2012) and 'Kagzi kalan' (Kakade et al., 2017). Style-expressed S-like-RNases and SKP1-like genes have been proposed to be involved in the SI response of the mandarin cv. 'Wuzishatangju' (Miao et al., 2011; Li et al., 2015). However, more research on the Citrus SI system will be needed before engineering SI for seedlessness will be practical.

\section{Molecular S-Genotyping for Successful Crossing and Marker-Assisted Breeding}

Specific knowledge of the level of cross-compatibility between cultivars is important to the seed and fruit industries. In species where the $S$-determinants have been identified, molecular genotyping has progressively replaced controlled pollinations, pollen tube growth tests, and enzymatic assays used to determine the $S$-genotype. Molecular genotyping also has accelerated the identification of new $S$-alleles, because it does not depend on environmental conditions and, in the case of trees, it does not require adult plants (Yamane and Tao, 2009). This has been especially useful for producers wishing to select efficient pollenizers (see Pollenizers and Orchard Management). For example, Sapir et al. (2008) reported that $87 \%$ of the Japanese plum germplasm grown in Israel contained only four $S$ haplotypes and this allowed them to focus their search for fully compatible cultivars. This is not an isolated example. Over the past 25 years, molecular $S$-genotyping has doubled the number of identified intercompatibility groups in most fruit tree species (Yamane and Tao, 2009). S-genotyping also has been used to design crosses and to select SC hybrids produced in breeding programs where, in many cases, SI parents are still needed.

In species with S-RNase-based SI, S-genotyping is usually based on the variability in intron sizes among the different $S$ - $R$ Nase alleles. It is noteworthy that Prunus spp., $S$-RNase genes contain two introns while all other species have a single $S$-RNase intron (Tao et al., 1999; Igic and Kohn, 2001). Often, conserved or specific primers flanking $S$-RNase introns are used to amplify PCR different sized products that are $S$-genotype specific. This approach has been extensively used for S-genotyping in many SI Rosaceae crop species, including pome and stone fruits (Table 1). High-throughput methods have also been 
developed for S-RNase-based S-genotyping. For instance, microarray platforms based on intron and cDNA sequences have been developed to identify $S$-RNase alleles in sweet cherry (Pasquer et al., 2008) and Asian pear (Pyrus pyrifolia Nakai) (Nan et al., 2015), respectively. In apple, Larsen et al. (2016) identified 25 SRNase alleles in 432 accessions by using multiplex PCR and fragment detection on a capillary DNA sequencer (Table $\mathbf{1}$ ).

$S$-genotyping is applicable when a single gene determines phenotype. This is the case for $S$-RNase, but also applies to other genes. In Prunus, a single $S F B$ gene specifies pollen-part behaviour so these genes also can be used for molecular $S$ genotyping. Vaughan et al. (2006) identified an intron in the sweet cherry SFB 5'untranslated region that shows allele-specific length polymorphism and used an automatic sequencer and fluorescent primers for $S$-genotyping. This method has also been widely applied in Japanese plum (Guerra et al., 2012) and apricot (Muñoz-Sanz et al., 2017b). In a related approach, that is independent of the S-locus per se, apricot self-(in)compatibility phenotypes were assessed by genotyping the SI modifier gene ParMDO at the M-locus (Muñoz-Sanz et al., 2017b). In Brassicaceae, extensive $S$-haplotyping in $B$. rapa and $B$. oleracea has been performed by dot-blot analysis with digoxigenin-labeled PCR products amplified from SP11 DNA sequences (Oikawa et al., 2011).

$S$-genotyping also may be applied to wild crop relatives. For example, cultivated tomato, potato, and coffee (Coffea arabica) are SC, but wild relatives carrying valuable pest and disease resistance traits are mostly SI (Dzidzienyo et al., 2016). Cultivated and wild diploid potatoes, however, are usually SI, so crosses to create pre-breeding materials can be facilitated by knowledge of their S-genotypes (Table 1). Similarly, coffee cultivars are SC tetraploids while its parent, C. canephora (robusta coffee), is diploid and mostly SI. Although SC C. arabica is more widely cultivated, C. canephora is also economically important and shows higher fitness, as do other wild relatives (Asquini et al., 2011). Thus, S-genotyping has been applied to wild Coffea species including C. canephora (Nowak et al., 2011). Selection of pollinizers based on S-genotyping is also relevant in this context since wild relatives are sometimes used. For example, wild crabapples (Malus spp.) may be used in commercial apple orchards to promote cross-pollination (Sheick et al., 2018).

$S$-genotyping also provides "value-added" markers for marker-assisted breeding. Over the last decade, SSRs and SNPs have become the "markers of choice" for genotyping. While SNPs are more numerous than SSRs, the latter have distinct advantages (Guichoux et al., 2011). One such benefit is the high mutation rate and multi-allelic nature of SSRs compared with SNPs, and this feature is shared by the $S$-locus. The extremely polymorphic nature of the $S$-locus is related to the frequencydependent selection on $S$-haplotypes inherent in SI: by definition, plants with rare $S$-haplotypes have more compatible mates than those with common $S$-haplotypes (Schueler et al., 2006). S-locus polymorphism can be applied in several ways. Although $S$-genotyping only provides information about a short stretch of the genome, breeding programs nevertheless use it to detect undesired crosses (e.g., accidental pollinations, or selffertilizations arising when SC females are used), or seed resulting from asexual reproduction. Molecular $S$-genotyping is also indicated when SI phenotyping is difficult and expensive, as with fruit trees. For instance, a DNA test based on the $S_{4}$ '-allele conferring SC in cherry, together with another test for fruit size, is now routinely used in a streamlined marker-assisted seedling selection scheme by a Pacific Northwest sweet cherry breeding program (Ru et al., 2015) and it is most likely used in all sweet cherry breeding programs implementing MAS. In another example, gene-specific $S$-locus markers have been developed at the Saskatoon Research and Development Center in Canada to select SC genotypes in yellow mustard (Sinapis alba L.) (Zeng and Cheng, 2014).

\section{SI as an Alternative to Androsterility for Developing Hybrids}

Hybrid vigor, or heterosis, occurs when two parents with different genetic backgrounds (usually pure lines) are crossed. Heterotic $F_{1}$ progeny show elevated yield as well as other agriculturally desirable traits, such as enhanced resistance to abiotic stresses. The phenomenon is widespread and, consequently, hybrid cultivars are common in many crop species, including maize, sorghum, tomato, and pepper (Kempe and Gils, 2011). Since most cultivated crops are SC, producing hybrid seed requires an efficient system to control pollination to prevent the female parent from self-fertilization. Control methods range from mechanical emasculation and chemical gametocide agents to nuclear or cytoplasmic-encoded male sterility (with fertility restoration in the $\mathrm{F}_{1}$ hybrid) (Kempe and Gils, 2011) (Figure 2A). SI has been reported to be preferred over male sterility in crop species with entomophilous pollination since pollen-collecting bees rarely visit male-sterile plants (Kaothien-Nakayama et al., 2010). Nonetheless, SI also may have disadvantages, for example, $F_{1}$ hybrids of two SI parents are also SI and this may be undesirable for crop production. SI $F_{1}$ hybrids are not a handicap for ornamental or vegetable crops, but it may hinder seed production (e.g., oilseed rape/canola) or fruit production (e.g., stone and pome) (Figure 2B). Consequently, breeding programs favor not only SI female lines, but also SC $\mathrm{F}_{1}$ hybrids (Kaothien-Nakayama et al., 2010).

\section{SI in Hybrid Breeding Schemes}

In Brassicaceae, SI is widely used for hybrid seed production in the generally SI diploid vegetables Brassica oleracea and B. rapa/ $B$. campestris. However, the derived amphi-diploid oilseed rape/ canola (B. napus) is naturally SC, and introgression of $S$-alleles from its parental species is required to produce hybrid seeds. Thus, Goring et al. (1992) introgressed the $S$-locus from the SI $B$. campestris 'W1' line into the SC B. napus cv. 'Westar' and developed an SI 'Westar' line by backcrossing. Later, Rahman (2005) resynthesized SI in B. napus by crossing SI B. oleraceae (cv. 'Green Duke') and B. rapa (cv. 'Horizon', 'Colt,' and 'AC Parkland') (Figure 2C). Success in restoring SI across species led to hopes that a deeper understanding of the molecular genetics of SI might allow it to be more used extensively in hybrid breeding. 
TABLE 1 | Molecular S-genotyping in crop species.

\begin{tabular}{|c|c|c|c|c|c|}
\hline Species & $\begin{array}{l}\text { S-alleles } / S- \\
\text { haplotypes }^{\mathrm{a}}\end{array}$ & Method & S-genes & $N^{b}$ & Refs. \\
\hline \multicolumn{6}{|l|}{ Brassicaceae } \\
\hline Cabbage, broccoli & $16\left(S^{a}-S^{p}\right)$ & PCR-RFLP ${ }^{\mathrm{c}}$ & $S L G$ & 40 & Park et al. (2001) \\
\hline Cabbage, cauliflower & 17 (Bo-Bob) & PCR-RFLP & SLG/SRK & 30 & Wang et al. (2007) \\
\hline Cabbage & 40 (BrS-) & Dot-blot & SP11 & 45 & Oikawa et al. (2011) \\
\hline \multicolumn{6}{|l|}{ (Brassica oleracea) } \\
\hline Turnip & 33 (BoS-) & Dot-blot & SP11 & 42 & Oikawa et al. (2011) \\
\hline $\begin{array}{l}\text { Chinese cabbage, etc. } \\
\text { (Brassica rapa) }\end{array}$ & 26 (Bc-Bcp) & PCR-RFLP & SLG/SRK & 38 & Wang et al. (2007) \\
\hline $\begin{array}{l}\text { Mustard } \\
\text { (Brassica juncea) }\end{array}$ & $1(\mathrm{Bj})$ & PCR-RFLP & SLG/SRK & 4 & Wang et al. (2007) \\
\hline Oilseed rape (Brassica napus) & $\begin{array}{l}4 / 2\left(S-\text { land } S-\|_{S L G}{ }^{a, b}\right) / \\
\left(S-\| I_{S P 11}{ }^{a, b}\right)\end{array}$ & PCR-CAPS & SLG/SP11 & 125 & Zhang X. et al. (2008) \\
\hline Radish & $18\left(S^{1}-S^{18}\right)$ & Southern & $S L G$ & 29 & Sakamoto et al. (1998) \\
\hline \multirow{3}{*}{ (Raphanus sativus) } & $\left.7 / 7\left(S_{1-10} / S_{1-10}\right)\right)^{a}$ & PCR-RFLP & SLG/SRK & 24 & Lim et al. (2002) \\
\hline & $\begin{array}{l}\text { 9/10 (Rs-SRK } 1-21 /- \\
\left.\text { SP1 }_{1-21}\right)^{\mathrm{a}}\end{array}$ & Sequencing & SRK/SP11 & 10 & Okamoto et al. (2004) \\
\hline & $15\left(\mathrm{RsS}_{1-40)}\right)^{\mathrm{a}}$ & Sequencing & $S L G / S R K$ & 63 & Wang et al. (2019) \\
\hline \multicolumn{6}{|l|}{ Rosaceae (tribe Amygdaleae) } \\
\hline $\begin{array}{l}\text { Apricot } \\
\text { (Prunus armeniaca) }\end{array}$ & $\begin{array}{l}30\left(\mathrm{~S}_{1}-\mathrm{S}_{20}, \mathrm{~S}_{22}-\mathrm{S}_{30}\right. \\
\left.\mathrm{S}_{\mathrm{C}}\right)\end{array}$ & $\begin{array}{l}\text { PCR/ } \\
\text { Sequencing }\end{array}$ & S-RNase/SFB & 261 & $\begin{array}{l}\text { Halázs et al. (2007a); Halázs } \\
\text { et al. (2010a); Zhang L. et al. } \\
\text { (2008); Wu et al. (2009); Lachkar } \\
\text { et al. (2013); Muñoz-Sanz et al. } \\
\text { (2017b); Herrera et al. (2018) }\end{array}$ \\
\hline $\begin{array}{l}\text { Japanese apricot } \\
\text { (Prunus mume) }\end{array}$ & $13\left(S^{1}-S^{11}, S^{f}, S^{3}\right)$ & PCR & S-RNase & 16 & Yamane and Tao (2009) \\
\hline $\begin{array}{l}\text { Japanese plum } \\
\text { (Prunus salicina) }\end{array}$ & $19\left(S^{a}-S^{s}\right)$ & PCR & SRNase/SFB & 149 & $\begin{array}{l}\text { Beppu et al. (2002); Beppu et al. } \\
\text { (2003); Sapir et al. (2004); Zhang } \\
\text { et al. (2007); Halázs et al. } \\
\text { (2007b); Guerra et al. (2009); } \\
\text { Guerra et al. (2012) }\end{array}$ \\
\hline \multicolumn{3}{|l|}{ (Prunus domestica) } & S-RNase & 16 & Halázs et al. (2014) \\
\hline Peach & $3\left(S^{1}, S^{2}, S^{2 m}, S^{3}, S^{4}\right)$ & PCR & S-RNase & 195 & $\begin{array}{l}\text { Hegedüs et al. (2006); Tao et al. } \\
\text { (2007); Hanada et al. (2014) }\end{array}$ \\
\hline (Prunus persica) & & PCR-CAPS & & & \\
\hline $\begin{array}{l}\text { Almond } \\
\text { (Prunus dulcis) }\end{array}$ & $34\left(S_{1}-S_{52}, S_{f}\right)^{a}$ & $\begin{array}{l}\text { PCR/ } \\
\text { Sequencing }\end{array}$ & S-RNase & 170 & $\begin{array}{l}\text { López et al. (2006); Ortega et al. } \\
\text { (2006); Kodad et al. (2008); } \\
\text { Halazs et al. (2010b); Currò et al. } \\
\text { (2015) }\end{array}$ \\
\hline $\begin{array}{l}\text { Sweet cherry } \\
\text { (Prunus avium) }\end{array}$ & $18\left(S^{1}-S^{24}\right)^{a}$ & $\begin{array}{l}\text { PCR-RFLP } \\
\text { PCR/ } \\
\text { Sequencing } \\
\text { Microarray }\end{array}$ & S-RNase/SFB & $\gtrsim 700$ & $\begin{array}{l}\text { Wiersma et al. (2001); Wunsch } \\
\text { and Hormaza (2004); Vaughan } \\
\text { et al. (2006); Schuster (2012); } \\
\text { Cachi and Wünsch (2014); } \\
\text { Pasquer et al. (2008) }\end{array}$ \\
\hline $\begin{array}{l}\text { Sour cherry } \\
\text { (Prunus cerasus) }\end{array}$ & $\begin{array}{l}15\left(S_{1-36}, S_{1}, S_{13}\right. \\
\left.S_{6 m-} S_{36 a-b-b 2}\right)^{a}\end{array}$ & PCR & S-RNase & 21 & Lisek et al. (2017) \\
\hline \multicolumn{6}{|l|}{ Rosaceae (tribe Maleae) } \\
\hline $\begin{array}{l}\text { Apple } \\
\text { (Malus x domestica) } \\
\text { Crabapple (Malus spp.) }\end{array}$ & $31\left(S^{1}-S^{46}\right)^{a}$ & $\begin{array}{l}\text { PCR-CAPS/ } \\
\text { PCR } \\
\text { Mplex PCR } \\
\text { PCR-RFLP }\end{array}$ & S-RNase & 596 & $\begin{array}{l}\text { Yamane and Tao (2009); Kim H. } \\
\text { T. et al. (2009); Long et al. } \\
\text { (2010); Larsen et al. (2016); } \\
\text { Sheick et al. (2018) }\end{array}$ \\
\hline $\begin{array}{l}\text { European pear } \\
\text { (Pyrus communis) }\end{array}$ & $21\left(\mathrm{~S}_{1}-\mathrm{S}_{24} ; \mathrm{Sm}\right)^{\mathrm{a}}$ & $\begin{array}{l}\text { PCR/ } \\
\text { Sequencing }\end{array}$ & S-RNase & 201 & $\begin{array}{l}\text { Sanzol and Robbins (2008); } \\
\text { Goldway et al. (2009); Sanzol } \\
\text { (2009); Quinet et al. (2014) }\end{array}$ \\
\hline $\begin{array}{l}\text { Japanese pear } \\
\text { (Pyrus pyrifolia) }\end{array}$ & $39\left(S^{1}-S^{52}, S^{4 s m}, S^{k}\right)^{a}$ & $\begin{array}{l}\text { PCR-RFLP/PCR } \\
\text { Microarray }\end{array}$ & S-RNase & 101 & $\begin{array}{l}\text { Yamane and Tao (2009); Gu } \\
\text { et al. (2009); Nashima et al. } \\
\text { (2015); Nan et al. (2015) }\end{array}$ \\
\hline $\begin{array}{l}\text { Loquat } \\
\text { (Eriobotrya japonica) }\end{array}$ & $13\left(S_{a}-S_{k}, S^{12}-S^{13}\right)$ & PCR & S-RNase & 150 & $\begin{array}{l}\text { Gisbert et al. (2009); Carrera } \\
\text { et al. (2011); Wang et al. (2017); } \\
\text { Zhang et al. (2017) }\end{array}$ \\
\hline
\end{tabular}


TABLE 1 | Continued

\begin{tabular}{|c|c|c|c|c|c|}
\hline Species & $\begin{array}{l}\text { S-alleles } / S- \\
\text { haplotypes }^{\text {a }}\end{array}$ & Method & S-genes & $N^{b}$ & Refs. \\
\hline \multicolumn{6}{|l|}{ Rubiaceae } \\
\hline $\begin{array}{l}\text { Coffee } \\
\text { (Coffea spp.) }\end{array}$ & $\begin{array}{l}14 \text { species including } \\
\text { C. arabica. } 36\left(\mathrm{~S}_{1-51}\right)^{\mathrm{a}}\end{array}$ & Sequencing & S-RNase & 58 & Nowak et al. (2011) \\
\hline \multicolumn{6}{|l|}{ Solanaceae } \\
\hline $\begin{array}{l}\text { Tomato } \\
\text { (Solanum subsection Lycopersicon) }\end{array}$ & $\begin{array}{l}5 \text { species including } S \text {. } \\
\text { arcanum, } S \text {. hirsutum, } \\
\text { etc. } 24\left(\mathrm{~S}_{6}-\mathrm{S}_{26}, \mathrm{~S}_{\mathrm{C}}\right)^{\mathrm{a}} \text {, } \\
\left(\mathrm{S}_{1}-\mathrm{S}_{2}\right) \text {, etc. } \\
\text { S. chilense } 30\left(\mathrm{~S}_{1}-\mathrm{S}_{30}\right)\end{array}$ & Sequencing & S-RNase & 21 & Kondo et al. (2002) \\
\hline $\begin{array}{l}\text { Potato } \\
\text { (Solanum subsection } \\
\text { Petota.) }\end{array}$ & $\begin{array}{l}5 \text { species including } S \text {. } \\
\text { chacoense, } S . S . \\
\text { stenotonum, etc. } 25 \\
\left(\mathrm{~S}_{2}-\mathrm{S}_{3}, \mathrm{~S}_{11}-\mathrm{S}_{16}\right),\left(\mathrm{Ss}_{1^{-}}\right. \\
\left.\mathrm{Ss}_{10}\right), \text { etc. }\end{array}$ & Sequencing & S-RNase & 14 & Dzidzienyo et al. (2016) \\
\hline
\end{tabular}

${ }^{a}$ Numbered non-consecutively.

${ }^{b} \mathrm{~N}$ Number of cultivars or accessions analyzed.

${ }^{c}$ Restriction Fragment Length Polymorphisms.

Transfer of cloned S-genes from SI Arabidopsis lyrata to its SC relative $A$. thaliana has resulted in appropriate pollen rejection (Nasrallah et al., 2002) (Figure 2C), but transfer into distantly related crop species has yet to be reported. Indeed, it is unlikely to be successful since Brassica SI requires modifier genes for proper function as explained in Molecular Mechanisms of SI. However, Papaver $S$-genes may allow specific pollen rejection in a wide variety of species. Unlike the S-RNase-based systems and the Brassica SSI system, the Papaver S-specificity determinants (PrpS and PrsS) are sufficient for SI function. Lin et al. (2015) reported a proof-of-principle experiment in which PrpS and PrsS genes from $P$. rhoeas were transferred to $A$. thaliana (Figure 2C). The results showed a specific rejection response in $A$. thaliana that resembled $P$. rhoeas SI pollen rejection. As $P$. rhoeas and $A$. thaliana are distantly related, these results are very promising. Engineered crop incompatibility using Papaver SI genes may soon become a reality and this is the subject of a patent discussed further below.

SI is also promising for developing hybrid breeding systems in grasses. For instance, wheat (Triticum aestivum L.) is a fully SC inbred species where hybrid breeding to exploit heterosis has been hindered, in part, by the difficulty of using male-sterility. However, SI is present in other grasses such as rye. Thus, it might be possible to introgress genes from close SI relatives to generate SI wheat (Whitford et al., 2013). All studied grasses exhibit a well-documented gametophytic SI system controlled by two multiallelic loci, $S$ and $Z$. In perennial ryegrass (Lolium perenne L.) two genes encoding DUF247 domain proteins of unknown function co-segregate with the $Z$ - (Shinozuka et al., 2010) and $S$ loci (Manzanares et al., 2016) and have been proposed as candidate $S$-genes. This fine-scale mapping of the L. perenne $S$ and $Z$-loci will facilitate the identification of haplotype-specific markers allowing cross compatibility to be predicted. Thus, selection based on $S$ - and Z-loci may be helpful for conventional ryegrass breeding where the inability to generate higher proportions of $F_{1}$ hybrids has limited genetic gains associated with heterosis. For instance, in standard semi-hybrid systems, two heterotic populations (synthetic varieties) are allowed to interpollinate at the final phase of seed production, generally resulting in 50\% hybrid seed. S-genotyping may improve this result. Simulations show that using two parental populations with restricted $S$-allele diversity (using linked markers for selection) may increase cross compatibility and generate up to $83.3 \% \mathrm{~F}_{1}$ hybrids (Pembleton et al., 2015) (Figure 2D). As a proof of concept, restriction of $S$-alleles in parent populations of the forage legume (Fabaceae) red clover (Trifolium pratense L.) allowed increased hybridity among seed produced. In controlled experiments, up to five populations containing just three $S$-alleles were randomly mated and compared to an $S$-allele unrestricted population. Only $48 \%$ of the seed from the unrestricted population was hybrid compared with $75 \%$ hybrids recovered from the restricted populations (Riday and Krohn, 2010) (Figure 2D).

\section{Ways of Achieving SC and Its Role in Hybrid Breeding}

Maintaining "pure" (highly homozygous) lines is also essential for hybrid breeding. Since SI species inherently favor outcrossing, achieving homozygosity may be hindered by the intra-specific crossing barrier itself and inbreeding depression. Maintaining SI parent lines with consistent properties may also be problematic. Consequently, breeders have used or considered a range of techniques to bypass SI including mentor pollen, bud and stump pollination, pollination of senescent flowers, irradiation, and high-temperature stress (De Nettancourt, 2001). Chemical treatments have also been employed. For example, treatment of pistils with $\mathrm{NaCl}$ or $\mathrm{CO}_{2}$ suppresses SI in SSI plants (Kučera et al., 2006). In vitro studies show that mixture of divalent zinc and copper ions inhibit S-RNases so it is conceivable this could suppress SI (Kim et al., 2001) (Figure 1A). More recently, a so-called "in vitro nursery" system has been suggested for SI crops. In this speculative scheme, gametes 

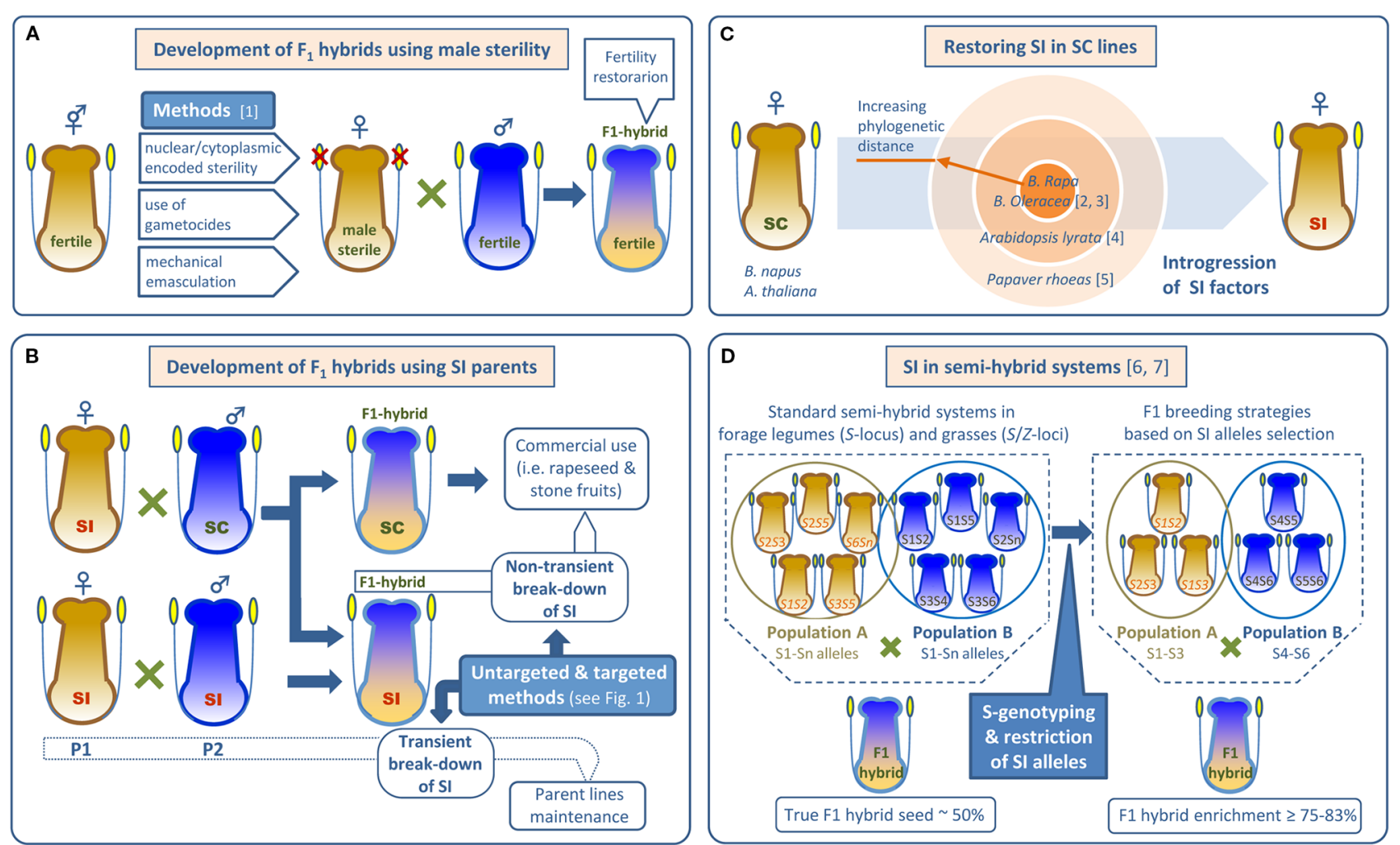

FIGURE 2 | Use of male-sterility and self-incompatibility in $F_{1}$ hybrid seed production. (A) Common methods to prevent self-fertilization of hermaphrodite female parents using male sterility. (B) SI based systems as alternatives to androsterility for producing F1 hybrids. Self-(in)compatible parents and F1 hybrids are indicated. (C) Introgression of SI factors from different gene pools to restore SI in Brassicaceae SC lines. (D) Increase in $\mathrm{F}_{1}$ hybrid production by restricting SI alleles in semihybrid systems. References: [1] Kempe and Gils (2011); [2] Goring et al. (1992); [3] Rahman (2005); [4] Nasrallah et al. (2002); [5] Lin et al. (2015); [6] Riday and Krohn (2010); [7] Pembleton et al. (2015).

generated from somatic cells might be fused (i.e., simulating selfpollination), to obtain homozygous lines that could subsequently be used to produce single cross hybrids (De La Fuente et al., 2013) (Figure 1A).

Sources of SC for hybrid breeding may also be derived from spontaneous or induced mutations associated with loss of SI function in pollen, stigmas, or styles (see also Different Sources of SC: A Favorable Trait for Yield Enhancement). An illustrative example is the use of the SC-inducing Sli (S-locus inhibitor) gene in diploid potato. Sli was discovered in a SC variant of the wild potato relative $S$. chacoense and mapped to the distal end of chromosome 12 (Hosaka and Hanneman, 1998a; Hosaka and Hanneman, 1998b). Although not yet characterized at the molecular level, the Sli gene has been shown to act as a single dominant pollen factor that causes sporophytic inhibition of GSI (Hosaka and Hanneman, 1998a). In addition to having potential implications for understanding the GSI mechanism (McClure et al., 2011), Sli was soon perceived as a useful "tool" for selfing diploid potato to develop highly homozygous and seedpropagated lines (Phumichai et al., 2005). Thus, Jansky et al. (2014) developed M6, a vigorous diploid SC S. chacoense line that displays $90 \%$ homozygosity (including Sli). M6 is fully fertile, produces seeds when crossed with cultivated or wild potatoes, and will enable systematic creation of inbred diploid lines. However, the introgression of the S. chacoense Sli gene into other potatoes is time-consuming and may carry along undesirable traits such as long stolons or high tuber glycoalkaloid content. CRISPR knock-out of the S-RNase gene has recently been shown to be another viable method to generate SC potato lines avoiding linkage drag of undesirable traits associated with Sli (Ye et al., 2018; Enciso-Rodriguez et al., 2019). This important milestone has implications for the replacement of the current tetraploid asexually propagated potato with a diploid inbred line-based crop propagated by seeds (Jansky et al., 2016).

In perennial grasses, SI is often used in synthetic and hybrid breeding schemes. However, SC provides advantages to breeders including uniformity and propagation of parental inbreds and reduction of genetic load. Several routes to SC have been documented in grasses, including $S$ - and $Z$-loci mutations (mainly pollen part defects) as well as other loci such as the $T$ (Thorogood et al., 2005) and the SF-loci (Do Canto et al., 2018). In practice, SC can be introgressed into populations of allogamous grasses by backcrossing. The derived inbred lines 
can be selected for heterozygosity at the $S$-locus using molecular markers, which would allow restoration of SI in the final synthetic varieties (Do Canto et al., 2016).

SC has been introduced in Brassica following both fairly traditional breeding methods as well as by directly manipulating S-gene expression (see Different Sources of SC: A Favorable Trait for Yield Enhancement). In one example, marker assisted selection (MAS) has been used to move two SC QTLs into SI cabbage (B. oleraceae) from line 87-534 (Xiao et al., 2019). One QTL, qSC7.2, was tightly linked with the S-locus, but the other, qSC9.1, was not associated to a known SI-related gene. Thus, although further research is needed to identify new SC genes, existing markers are already useful for MAS of SC (Xiao et al., 2019). Tantikanjana and Nasrallah (2015) proposed an alternative inducible SC system. It was mentioned earlier that expression of functional S-genes from Arabidopsis lyrata in SC A. thaliana pollen and stigmas causes SI. However, Tantikanjana and Nasrallah (2015) discovered that co-expression of both the A. lyrata SRK and SCR genes in A. thaliana stigma epidermal cells leads to ligand-mediated cis-inhibition of SRK and, thus, disrupts SI. This led them to propose two cis-SCR-based strategies for hybrid-seed production. Both strategies use a heat inducible promoter to allow inducible SC in otherwise SI inbreds (i.e., for maintenance) and in $\mathrm{F}_{1}$ hybrids for large-scale seed production.

\section{Overcoming Interspecific Reproductive Barriers (IRBs)}

Interspecific hybridization is of great interest to plant breeders because valuable agronomic traits could, in principle, be captured by crossing with crop wild relatives. Wild genetic resources may find a variety of applications such as sources of biotic and abiotic stress resistances for use in elite cultivars. Other examples include generating interspecific hybrids for use as rootstocks and developing introgression lines for QTL mapping (Haussmann et al., 2004).

Accessing wild crop relative germplasm often first requires overcoming interspecific reproductive barriers (IRBs). Breeders have employed strategies similar to those used to mitigate intraspecific barriers: radiation-induced mutagenesis, mentor pollen, bud-pollination, temperature stress, and style removal (De Nettancourt, 2001; Van Tuyl and De Jeu, 2005). While these strategies have often succeeded, IRBs still represent an impediment to introgressing desired traits from wild relatives into certain crop-genera, including Solanum (Jansky, 2006; Bedinger et al., 2011), Prunus (Liu et al., 2007), Cucumis (Matsumoto and Miyagi, 2012), and Fagopyrum (buckwheat) (Mendler-Drienyovszki et al., 2013).

IRBs have been discussed in terms of two broad concepts, incompatibility and incongruity, that are best understood as distinct phenomena. Incompatibility describes pollinations that fail because an induced or constitutive pollen rejection mechanism. On the other hand, pollination can also fail because of divergent evolution and we regard this as incongruity. In an extreme example, wind-blown grass pollen may well land on a wet Solanaceae-type stigma, but this is not a congenial environment for germination and growth. These concepts are very helpful for understanding IRBs, but it is naïve to regard them as mutually exclusive.

Studies of interspecific unilateral incompatibility (UI) have helped elucidate the relationships between IRBs and SI. Since UI has been described in crop-families including Solanaceae, Poaceae, Brassicaceae, etc. (De Nettancourt, 2001), elucidating the mechanisms could be helpful to breeders. UI is defined as a form of incompatibility where crosses are successful in one direction, but not the other. Compatibility in one direction suggests that the parents are not so divergent that incongruity determines pollination behavior, so the failure of the opposite cross should be understood as incompatibility (Hancock et al., 2003). Often, UI follows the SI $\times$ SC rule (Lewis and Crowe, 1958) where SI species' pistils reject pollen from SC species, but the reciprocal crosses are compatible. Although $\mathrm{SI} \times \mathrm{SC}$ UI relationships are common, UI can also occur in $\mathrm{SC} \times \mathrm{SC}$ or $\mathrm{SI} \times \mathrm{SI}$ interspecific crosses, but the latter are likely to be mechanistically distinct.

The first steps toward elucidating the mechanisms of UI have been taken in Nicotiana and Solanum. UI conforming to the $\mathrm{SI} \times \mathrm{SC}$ rule is very common in these genera suggesting that SI and UI are linked. Murfett et al. (1996) tested this hypothesis and confirmed that Nicotiana S-RNases are involved in some types of UI. Thus, S-RNases were the first factors identified as playing a role in pistil-side UI function, reinforcing a connection between SI and UI. However, the results also showed a requirement for additional (i.e., non-S-RNase) pistil-side factors in some types of UI (Murfett et al., 1996; McClure et al., 2000).

Genetic studies implicated QTL on Solanum chromosomes 1, 3, and 12 in pistil-side UI function (Bernacchi and Tanksley, 1997), and additional evidence suggested that the chromosome 1 and 12 factors might correspond to S-RNase and HT-genes, respectively (Covey et al., 2010). Tovar-Méndez et al. (2014) tested this hypothesis by introducing functional $S$-RNase and $H T$-genes into cultivated tomato (S. lycopersicum) and reported that expressing both genes created a pollination barrier similar to the natural IRB separating the SC red/orange-fruited clade from the predominantly SI green-fruited species (Figures 3A, B). Neither S-RNase nor HT alone was sufficient to create the UI barrier. Thus, it is very clear that pistil-expressed SI genes contribute to some types of interspecific UI. However, it is also clear that other UI mechanisms also contribute. For example, some SC accessions lacking $S$-RNase still display UI (i.e., UI exists in certain $\mathrm{SC} \times \mathrm{SC}$ crosses). Intriguingly, HT-dependent SRNase independent IRBs also have been reported in Solanum (Tovar-Méndez et al., 2017) (Figure 3B).

Pollen-side factors are also shared between SI and interspecific UI. Chetelat and DeVerna (1991) found genetic evidence for multiple UI factors and described major QTL controlling pollenside UI expression on S. pennellii chromosomes 1, 6, and 10. Li et al. (2010) subsequently fine-mapped the ui6.1 locus and identified the underlying gene as a pollen-expressed cullin gene (CUL1) that functions in both SI and interspecific UI ( $\mathrm{Li}$ and Chetelat, 2010; Li and Chetelat, 2014). Later, the ui1.1 locus was associated with a particular S. pennellii SLF gene, SpSLF-23, 
further strengthening the connection between SI and UI (Li and Chetelat, 2015) (Figure 3B). Notwithstanding this relationship, Qin et al. (2018) recently identified an SI independent UI barrier in $S$. pennellii regulated by the pollen-expressed farnesyl pyrophosphatase synthase gene FPS2 (Figure 3B).

Knowledge about mechanisms controlling interspecific barriers remains limited. However, in Nicotiana and Solanum, interspecific barriers have been directly manipulated (Murfett et al., 1996; Li and Chetelat, 2010; Tovar-Méndez et al., 2014; Tovar-Méndez et al., 2017) (Figure 3B). The Solanum model provides an excellent example. These studies show that UI mechanisms are $S$-locus dependent; silencing or overexpressing $S$-RNases could be useful for modifying both SI/SC phenotypes as well as UI. SI and UI are also likely to be related in other crop families, so it is possible that the Solanum results can be extended. For example, although more evidence is needed, preliminary results could suggest linkage between SI and UI in Prunus (Rosaceae), so this genus may be amenable to manipulation (Morimoto et al., 2019).

\section{Patented Applications of Plant SI Systems}

The increasing number of SI-related patents attests to the commercial interest in practical application of SI. Data in Table $\mathbf{2}$ were obtained from the PatentScope database (World Intellectual
Property Organization) and list some of the most relevant SIrelated patents since 2009, though the earliest SI-related patents date from the mid-1980s. Many of these were awarded to public institutions and universities, but private interests in the United States of America, China, and European Union are also represented. The patents are mainly focused on transgenic manipulation of SI and make claims including SI suppression, $\mathrm{F}_{1}$ hybrid production, overcoming interspecific barriers, and $S$ genotyping. Patents are based on SI factors from Papaveraceae, Brassicaceae, and Solanaceae, but also on the manipulation of SI in less studied families such as Poaceae and Orchidaceae.

The relatively recent discovery that elements of the Papaver SI system may be used to transfer SI to unrelated species is especially noteworthy. The identity of the $S$-determinants and the physiological SI mechanism are briefly described in Molecular Mechanisms of SI and elsewhere (Wilkins et al., 2014). The dramatic demonstration that appropriate expression of PrsS and PrpS can confer SI on otherwise SC A. thaliana (De Graaf et al., 2012; Lin et al., 2015) formed the basis for the patent titled "Engineering of plants to exhibit self-incompatibility" by FranklinTong et al. (2010). This was not the first successful transfer of SI genes into A. thaliana, as Nasrallah et al. (2002) restored SI in A. thaliana by introducing SI genes from A. lyrata. However, the successful transfer of SI over the enormous phylogenetic distance
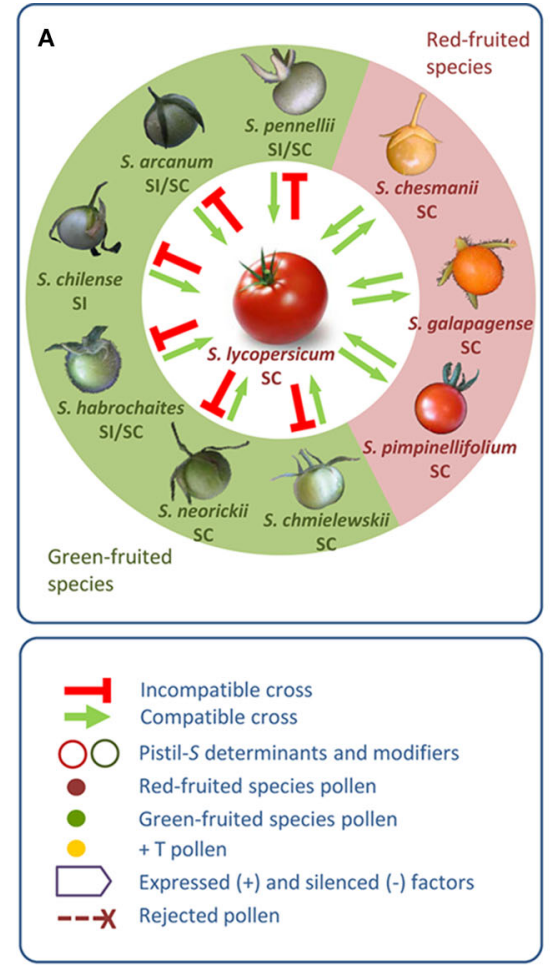

B
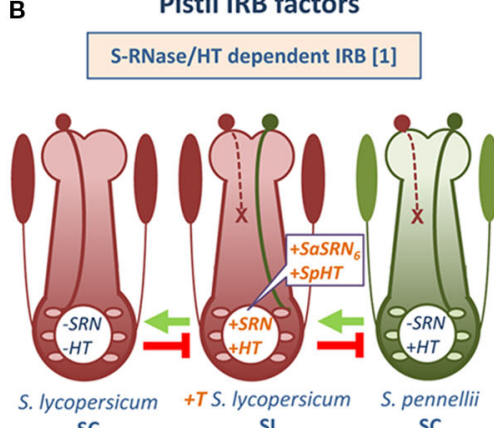

SC

S-RNase independent HT dependent IRB [2]

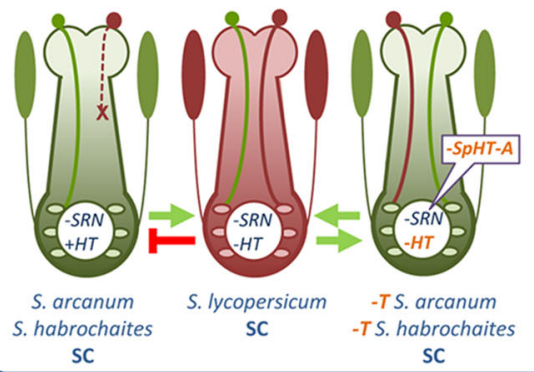

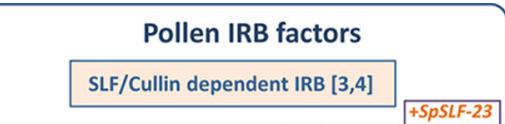

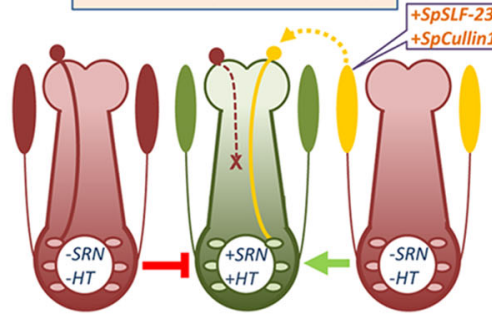

S. lycopersicum S. lycopersicum $x+T$ S. lycopersicum SC S. lycopersicoides IL (S. pennellii) allotriploid tester

S-RNase independent IRB [5]

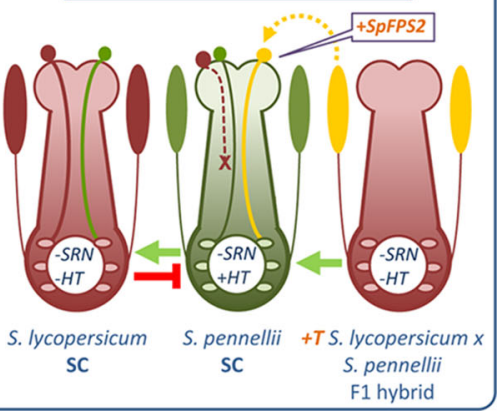

FIGURE 3 | Interspecific Reproductive Barriers (IRBs) in Solanum. (A) Compatibility and incompatibility between S. lycopersicum and red- and green-fruited wild Solanum species. Direction of compatible and incompatible crosses is indicated by green arrowed and red lines, respectively. (B) Modification of IRBs in Solanum by introducing (+T) and/or knocking out (-T) pistil and pollen factors. Each modified IRB is indicated and referred: [1]Tovar-Méndez et al., 2014; [2] Tovar-Méndez et al., 2017; [3] Li and Chetelat, 2010; [4] Li and Chetelat, 2015; [5] Qin et al., 2018. Pollen and pistil transgenes are orange-colored. SC, self-compatible; SI, self-incompatible; FPS2, Farnesyl pyrophosphatase synthase gene; SRN, S-RNase gene; SLF, S-locus F-box gene; HT, HT gene; Sp, Solanum pennelli; Sa, Solanum arcanum. 
TABLE 2 | Patent applications related to self-incompatibility ${ }^{\text {a }}$.

\begin{tabular}{|c|c|c|c|c|c|c|}
\hline Pub. $n^{\circ}$ & Title & Major claims & Potential uses & $\begin{array}{c}\text { Crop } \\
\text { species }\end{array}$ & Applicant (country) & Reference \\
\hline CN 109750061 & $\begin{array}{l}\text { Method for overcoming } \\
\text { diploid potato self- } \\
\text { incompatibility }\end{array}$ & $\begin{array}{l}\text { Development } \\
\text { of diploid SC potatoes } \\
\text { by knocking-out } S \text { - } \\
\text { RNases usingCRISPR- } \\
\text { Cas9 gene editing }\end{array}$ & $\begin{array}{l}\text { - } \quad \text { Breakdown of SI } \\
\text { Development of SC diploid } \\
\text { lines for potato breeding }\end{array}$ & Potato & $\begin{array}{l}\text { Agricultural Genomics } \\
\text { Institute. Academy of } \\
\text { Agricultural Sciences } \\
\text { (China) }\end{array}$ & $\begin{array}{l}\text { Sanwen } \\
\text { et al., } 2019\end{array}$ \\
\hline CN 106258956 & $\begin{array}{l}\text { Pedigree breeding and wild } \\
\text { transplanting method of } \\
\text { Dendrobium officinale }\end{array}$ & $\begin{array}{l}\text { Treatment of pistils with a } \\
\text { pollination accelerator } \\
\text { (based on Indole Acetic } \\
\text { Acid) to disturb SI }\end{array}$ & $\begin{array}{l}\text { Improve the success rate } \\
\text { and setting percentage of } \\
\text { self-pollination }\end{array}$ & $\begin{array}{l}\text { Dendrobium } \\
\text { officinale }\end{array}$ & $\begin{array}{l}\text { Sichuan Qiancao } \\
\text { Biotechnology Co., } \\
\text { Ltd. (China) }\end{array}$ & $\begin{array}{l}\text { Xin et al., } \\
2017\end{array}$ \\
\hline $\begin{array}{l}\text { WO/2016/ } \\
137029\end{array}$ & $\begin{array}{l}\text { Primer set for assessing } \\
\text { combination purity or } \\
\text { discriminating genotype of } \\
\text { cabbage class-II SI factor }\end{array}$ & $\begin{array}{l}\text { Class-II } \\
\text { SRK genotyping by } \\
\text { specific PCR } \\
\text { amplification }\end{array}$ & $\begin{array}{l}\text { - Assess purity and } \\
\text { discriminate genotypes to } \\
\text { enhance hybrid seed } \\
\text { production efficiency }\end{array}$ & Cabbage & $\begin{array}{l}\text { Industry-Academic } \\
\text { Cooperation } \\
\text { Foundation of } \\
\text { Sunchon National } \\
\text { University (Korea) }\end{array}$ & $\begin{array}{l}\text { Kang et al., } \\
2016\end{array}$ \\
\hline $\begin{array}{l}\text { US 2015/ } \\
0322445\end{array}$ & $\begin{array}{l}\text { SI system for making } \\
\text { Brassicaceae hybrids }\end{array}$ & $\begin{array}{l}\text { Co-expression of } \\
\text { Lal2and SCRL } \\
\text { (SRK and SCR putative } \\
\text { orthologs in } \\
\text { Leavenworthia } \\
\text { alabamica) polypeptides } \\
\text { for conferring SI }\end{array}$ & $\begin{array}{l}\text { - } \quad \text { Restoring of } \mathrm{SI} \\
\text { Obtaining of } \mathrm{F}_{1} \text { hybrids for } \\
\text { producing industrial grade } \\
\text { oil }\end{array}$ & $\begin{array}{l}\text { Brassicaceae } \\
\text { (Camelina } \\
\text { sativa) }\end{array}$ & $\begin{array}{l}\text { The Royal Institution } \\
\text { for the Advancement } \\
\text { of Learning/McGill } \\
\text { Univ. (Canada) }\end{array}$ & $\begin{array}{l}\text { Schoen and } \\
\text { Chantha, } \\
2015\end{array}$ \\
\hline $\begin{array}{l}\text { WO/2014/ } \\
127414\end{array}$ & Manipulation of SI in plants & $\begin{array}{l}\text { - A method for controlling } \\
\text { hybridization } \\
\text { - } S \text { and } Z \\
\text { haplotype candidate } \\
\text { gene isolation } \\
\text { - } \quad \text { Kit for controlling SI }\end{array}$ & $\begin{array}{l}\text { - } \quad \text { Production of } \mathrm{F}_{1} \text { hybrids } \\
\text { - } \quad \text { Breakdown of } \mathrm{SI}\end{array}$ & $\begin{array}{l}\text { Poaceae } \\
\text { (ryegrass } \\
\text { [Lolium spp.] } \\
\text { and fescue } \\
\text { [Festuca } \\
\text { spp.]) }\end{array}$ & $\begin{array}{l}\text { Agriculture Victoria } \\
\text { Services Pty Ltd } \\
\text { (Australia) }\end{array}$ & $\begin{array}{l}\text { Spagenberg } \\
\text { et al., } 2014\end{array}$ \\
\hline $\begin{array}{l}\text { WO/2014/ } \\
115680\end{array}$ & $\begin{array}{l}\text { Method for breeding } \\
\text { Brassica rapa plant having } \\
\text { SC }\end{array}$ & $\begin{array}{l}\text { A method to inactivate } \\
\text { pollen-S factor SP11 } \\
\text { while maintaining the } \\
\text { inverted repeat } \\
\text { sequence (SMI) on a } \\
\text { class-I dominant } S \text { - } \\
\text { haplotype }\end{array}$ & $\begin{array}{ll}\text { - } & \text { Breakdown of } \mathrm{SI} \\
\text { - } & \text { Production of } \mathrm{F}_{1} \text { hybrids } \\
& \text { high seed-producing } \\
& \text { hybrids for edible or } \\
\text { biodiesel purposes }\end{array}$ & Brassicaceae & $\begin{array}{l}\text { National University } \\
\text { Corporation Nara } \\
\text { Institute of Science } \\
\text { and Technology } \\
\text { (Japan) }\end{array}$ & $\begin{array}{l}\text { Takayama } \\
\text { and Uno, } \\
2014\end{array}$ \\
\hline CN 103710316 & $\begin{array}{l}\text { Solanum chilense SCF } \\
\text { complex CUL1 subunit } \\
\text { protein sequence and } \\
\text { nucleotide sequence }\end{array}$ & $\begin{array}{l}\text { CUL1 over-and/or } \\
\text { under-expression by } \\
\text { genetic engineering }\end{array}$ & $\begin{array}{l}\text { Overcoming incompatibility } \\
\text { of distant hybridization } \\
\text { with wild tomatoes } \\
\text { Further research of SI } \\
\text { mechanism }\end{array}$ & Solanaceae & $\begin{array}{l}\text { Shanghai Jiao Tong } \\
\text { University (China) }\end{array}$ & $\begin{array}{l}\text { Zhao et al., } \\
2014\end{array}$ \\
\hline $\begin{array}{l}\text { WO/2014/ } \\
029861\end{array}$ & $\begin{array}{l}Z \text { locus SI alleles in } \\
\text { Poaceae }\end{array}$ & $\begin{array}{l}\text { Identification of two } \\
\text { glycerol kinase-like } \\
\text { linked genes, LpGK1 } \\
\text { and LpGK2, encoded } \\
\text { by the } Z \text { SI locusin } \\
\text { perennial ryegrass }\end{array}$ & $\begin{array}{ll}\text { - } & \text { Breakdown of } \mathrm{SI} \\
\text { - } & \text { Production of } \mathrm{F}_{1} \text { hybrids } \\
\text { - } & \text { Genotyping of } Z \text {-alleles } \\
\text { - } & \text { Search for } Z \text { locus } \\
\text { orthologs in Poaceae spp. }\end{array}$ & Poaceae & $\begin{array}{l}\text { Aarhus Universitet } \\
\text { (Denmark) }\end{array}$ & $\begin{array}{l}\text { Studer and } \\
\text { Asp, } 2014\end{array}$ \\
\hline 1020120001465 & $\begin{array}{l}\text { RNA interference cassette } \\
\text { for SI factor of Brassica } \\
\text { spp. and a vector } \\
\text { containing the same }\end{array}$ & $\begin{array}{l}\text { A vector containing a } \\
\text { promoter, RNAi } \\
\text { cassette with a } \\
\text { SP11 pollen-S factor } \\
\text { antisense from Brassica } \\
\text { rapa, GUS }{ }^{\text {b }} \text { region, and } \\
\text { SP11 sense }\end{array}$ & - $\quad$ Breakdown of SI & Brassicaceae & $\begin{array}{l}\text { Industry-Academy } \\
\text { Coop. Corps of } \\
\text { Sunchon National } \\
\text { University (Korea) }\end{array}$ & $\begin{array}{l}\text { Shin et al., } \\
2012\end{array}$ \\
\hline CN 102234324 & $\begin{array}{l}\text { Protein involving SI and } \\
\text { cross-compatibility control } \\
\text { of phanerogam pollen, } \\
\text { coding gene thereof, and } \\
\text { application }\end{array}$ & $\begin{array}{l}\text { A vector containing a } \\
\text { promoter } \\
\text { and an RNAi cassette } \\
\text { with a PhSSK1 pollen } \\
\text { factor antisense from } \\
\text { Petunia hybrida }\end{array}$ & - $\quad$ Breakdown of SI & Solanaceae & $\begin{array}{l}\text { Institute of Genetics } \\
\text { and Developmental } \\
\text { Biology, Chinese } \\
\text { Academy of Sciences } \\
\text { (China) }\end{array}$ & $\begin{array}{l}\text { Zhao et al., } \\
2011\end{array}$ \\
\hline $\begin{array}{l}\text { WO/2010/ } \\
061181\end{array}$ & $\begin{array}{l}\text { Engineering of plants to } \\
\text { exhibit SI }\end{array}$ & $\begin{array}{l}\text { Use of multi-allelic } \\
\text { pollen- (PrpS) and pistil- } \\
\text { expressed (PrsS) } \\
\text { genes of the common }\end{array}$ & 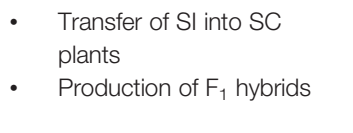 & Papaver & $\begin{array}{l}\text { The University of } \\
\text { Birmingham (United } \\
\text { Kingdom) }\end{array}$ & $\begin{array}{l}\text { Franklin- } \\
\text { Tong et al., } \\
2010\end{array}$ \\
\hline
\end{tabular}


TABLE 2 | Continued

\begin{tabular}{|c|c|c|c|c|c|c|}
\hline Pub. $n^{\circ}$ & Title & Major claims & Potential uses & $\begin{array}{c}\text { Crop } \\
\text { species }\end{array}$ & Applicant (country) & Reference \\
\hline 1020090053403 & $\begin{array}{l}\text { Primer set detecting SLG } \\
\text { and SRK genotypes of } \\
\text { radish SI }\end{array}$ & $\begin{array}{l}\text { field poppy (Papaver } \\
\text { rhoeas) to confer SI on } \\
\text { plants which do not } \\
\text { possess a SI system } \\
\text { - A primer set for } \\
\text { detecting SLG } \\
\text { genotype in radish. } \\
\text { A PCR method using } \\
\text { the primer set } \\
\text { determine radish the } \\
\text { genotype identity }\end{array}$ & $\begin{array}{l}\text { Prolong 'shelf-life' in } \\
\text { ornamental plants and cut } \\
\text { flowers } \\
\text { - Detect SI genotype of radish } \\
\text { to prevent the failure of } \\
\text { pollination and hybridization } \\
\text { between radishes having the } \\
\text { same SI genotype }\end{array}$ & Radish & $\begin{array}{l}\text { Republic of Korea } \\
\text { (management: rural } \\
\text { development } \\
\text { administration) } \\
\text { (Korea) }\end{array}$ & $\begin{array}{l}\text { Kim K. T. } \\
\text { et al., } 2009\end{array}$ \\
\hline
\end{tabular}

${ }^{a}$ Data retrieved from the Patentscope database (WIPO, World Intellectual Property Organization), both national and international patent collections.

${ }^{b}$ GUS ( $\beta$-glucuronidase reporter gene).

between Papaver and Arabidopsis suggests that the Papaver system may find wide application. This Papaver based technology may offer advantages for crop breeding and production. Examples of potential applications include use as an alternative to male sterility for $F_{1}$ hybrid production in species such as maize and rice, or as a means to avoid pollination induced senescence, thereby enhancing "shelf-life" of ornamentals or cut flowers, or preventing seed set in biomass crops. The Papaver SI-PCD system has also been envisioned as a potential research tool. For instance, McClure (2011) noted that $\operatorname{PrpS}$ genes might be used in cell fate studies to test the effects of removing specific cell populations by expressing the genes with celltype-specific promoters and treating with the appropriate incompatible PrsS protein.

As noted, the grass GSI system is controlled by two multiallelic loci, $S$ - and $Z$-, but the genes have not been positively identified. Nevertheless, two different patents have claimed the identification and use of $S$ - and $Z$ - candidate genes responsible for SI. Studer and Asp (2014) reported two glycerol kinase-like linked genes (LpGK1 and $L p G K 2$ ) as $Z$-locus candidates in perennial ryegrass. $Z$-allele specific variable regions in these genes allow prediction of $Z$-locus incompatibility phenotype and will be useful to control pollination in hybrid breeding systems. Spagenberg et al. (2014) reported the identification of a collection of genes located at the $S$ - and Z-loci in perennial ryegrass and propose that modification (by gene editing) or selection (by using linked markers) of these genes might be useful for controlling hybridization.

Patents also have been issued taking advantage of the Brassicaceae and Solanaceae SI factors. Some highlights are mentioned to illustrate the range of applications. For instance, Shin et al. (2012) patented a system to suppress SI by blocking expression of the Brassica SP11 pollen-S factor using RNAi. Takayama and Uno (2014) patented a non-transgenic method to inactivate SP11 in Brassica rapa. This method involves crossing plants with class II $S$-haplotypes and plants carrying a dominant class I S-haplotype, but lacking SP11. This could be utilized in hybrid production of edible or biodiesel Brassica crops. Working in the opposite direction, Schoen and Chantha (2015) patented a method to restore SI, by co-expressing putative SRK and SCR orthologs from Leavenworthia alabamica in SC Camelina sativa to obtain $\mathrm{F}_{1}$ hybrids for producing industrial oils. In Solanaceae, Zhao et al. (2011) patented a system for eliminating SI in Petunia hybrida by suppressing SLF-interacting-SKP1-like gene (SSK) expression with RNAi. Zhao et al. (2014) patented the Solanum chilense CUL1 sequence for use as a tool to overcome hybridization barriers in wild tomatoes. Recently, Sanwen et al. (2019) patented a procedure to knockout potato S-RNases using CRISPR-Cas9 as a means to develop potato diploid SC lines. In the genotyping domain, Kim K. T. et al. (2009) developed a method for S-genotyping radish (Raphanus sativus) cultivars by PCR-amplifying SLG alleles and, similarly, in cabbage Kang et al. (2016) patented a primer set for genotyping the SRK gene to assess combination purity.

SI-related patents have also been issued in species with unknown SI genetics. For instance, Dendrobium species are of interest as ornamental and medicinal plants, but show a high rate of SI and the system has not been characterized (Niu et al., 2018). Thus, in Dendrobium officinale (Orchidaceae) a method has been patented for overcoming SI using a pollination accelerator based on indole acetic acid (Xin et al., 2017).

\section{FUTURE PROSPECTS}

Table 3 presents a partial list of potential applications across a variety of crops. As noted, understanding the molecular basis of SI has enabled targeted manipulations for breeding and crop production. However, much remains to be learned and deeper knowledge may facilitate further improvements or enlarge the scope of possible applications. For instance, full molecular dissection of known SI systems may provide additional gene targets for creating SC (i.e. Glyoxylase I in canola, ParMDO in apricot, etc.). Furthermore, studies of as yet uncharacterized SI systems may facilitate applications (e.g., S-genotyping enabled pollenizer selection, developing SC cultivars, or hybrid breeding) in crops like tea, cocoa, olive, etc.

There are some notable areas where improved understanding may contribute. Advances in omics and genome editing technologies are increasing the pace of identification of new SI factors. Nevertheless, omics studies in some species (e.g., tea, citrus, etc.) are exploratory and research is still needed before practical applications can commence. Besides analyzing the role 
TABLE 3 | Potential applications of SI research in crop breeding and production.

\begin{tabular}{ccc}
\hline Crop type & SI system & SI/SC $^{\text {a }} \quad$ Potential applications of SI $_{\text {research }}$
\end{tabular}

\begin{tabular}{|c|c|c|c|c|}
\hline \multicolumn{5}{|l|}{ Cereals crops } \\
\hline $\begin{array}{l}\text { Wheat } \\
\text { (Triticum aestivum) }\end{array}$ & GSI (S- and Z-loci) ${ }^{\mathrm{a}}$ & SC & $\begin{array}{l}\text { Introgression of } \mathrm{SI} \text { from close } \\
\text { relatives for developing hybrid } \\
\text { seeds }\end{array}$ & Whitford et al. (2013) \\
\hline \multicolumn{5}{|l|}{ Oilseed crops } \\
\hline $\begin{array}{l}\text { Oilseed rape-canola } \\
\text { (Brassica napus) }\end{array}$ & SSI & SC & $\begin{array}{l}\text { Identification of new targets for } \\
\text { inducing SC and methods to } \\
\text { propagate SI lines for hybrid } \\
\text { breeding }\end{array}$ & Yang et al. (2018) \\
\hline $\begin{array}{l}\text { Yellow mustard } \\
\text { (Sinapis alba) }\end{array}$ & SSI & SI & $\begin{array}{l}\text { - Development of } \mathrm{SI} \text { and } \mathrm{SC} \\
\text { inbred lines to produce high } \\
\text { yielding synthetic varieties }\end{array}$ & Zeng and Cheng (2014) \\
\hline \multicolumn{5}{|l|}{ Vegetable crops } \\
\hline $\begin{array}{l}\text { Tomato } \\
\text { (Solanum lycopersicum) }\end{array}$ & $\begin{array}{l}\text { S-RNase based GSI } \\
\text { Non-self recognition }\end{array}$ & SC & $\begin{array}{l}\text { - Introgression of crop wild relative } \\
\text { traits into elite cultivars by } \\
\text { overcoming IRBs depending on } \\
\text { SI } \\
\text { Development of ILs for genetic } \\
\text { analysis }\end{array}$ & Tovar-Mendez et al. (2017) \\
\hline $\begin{array}{l}\text { Cabbage, broccoli, etc. } \\
\text { (Brassica oleracea) }\end{array}$ & SSI & SI & $\begin{array}{l}\text { - Identification of new target genes } \\
\text { conferring SC } \\
\text { Development of SC lines for } \\
\text { hybrid breeding }\end{array}$ & Xiao et al. (2019) \\
\hline \multicolumn{5}{|l|}{ Tuber and root crops } \\
\hline $\begin{array}{l}\text { Potato } \\
\text { (Solanum tuberosum) }\end{array}$ & $\begin{array}{l}\text { S-RNase based GSI } \\
\text { Non-self recognition }\end{array}$ & $\mathrm{SI} / \mathrm{SC}$ & $\begin{array}{l}\text { Development of new CRISPR- } \\
\text { KO SC diploid lines for efficient } \\
\text { inbred/F1 hybrid strategies }\end{array}$ & Ye et al. (2018); Enciso-Rodriguez et al. (2019) \\
\hline $\begin{array}{l}\text { Radish } \\
\text { (Raphanus sativus) }\end{array}$ & SSI & SI & $\begin{array}{l}\text { S-genotyping for selecting weak } \\
\text { SI plants as male and maintainer } \\
\text { lines for hybrid breeding }\end{array}$ & Wang et al. (2019) \\
\hline \multicolumn{5}{|l|}{ Fruit crops } \\
\hline $\begin{array}{l}\text { Cherry, almond, apricot, } \\
\text { and plum (Prunus spp.) }\end{array}$ & $\begin{array}{l}\text { S-RNase based GSI } \\
\text { Self recognition }\end{array}$ & $\mathrm{SI} / \mathrm{SC}$ & $\begin{array}{l}\text { - Identification of new SC sources } \\
\text { Development of new interspecific } \\
\text { hybrids on the basis of possible } \\
\text { relation between SI and IRBs }\end{array}$ & Muñoz-Sanz et al. (2017b); Morimoto et al. (2019) \\
\hline $\begin{array}{l}\text { Apple, pear, and loquat (Rosaceae } \\
\text { subf. Maloideae) }\end{array}$ & $\begin{array}{l}\text { S-RNase based GSI } \\
\text { Non-self recognition }\end{array}$ & $\mathrm{SI} / \mathrm{SC}$ & $\begin{array}{l}\text { - S-genotyping for identifying new } \\
\text { pollenizers }\end{array}$ & Claessen et al. (2019); Sheick et al. (2018) \\
\hline $\begin{array}{l}\text { Orange, mandarin, lemon } \\
\text { (Citrus spp.) }\end{array}$ & Unknown $(G S I)^{a}$ & SC & $\begin{array}{l}\text { - Development of new SC cultivars } \\
\text { - Introgression of SI to reinforce } \\
\text { seedlessness in commercial } \\
\text { cultivars }\end{array}$ & Li et al. (2015); Kakade et al. (2017) \\
\hline $\begin{array}{l}\text { Olive tree } \\
\text { (Olea europaea) }\end{array}$ & Unknown (DSI) ${ }^{\mathrm{a}}$ & SI & $\begin{array}{ll}\text { - } & \text { S-genotyping for selecting } \\
& \text { pollenizers } \\
\text { - } & \text { Development of SC cultivars }\end{array}$ & Saumitou-Laprade et al. (2017) \\
\hline \multicolumn{5}{|l|}{ Beverage crops } \\
\hline $\begin{array}{l}\text { Robusta coffee } \\
\text { (Coffea canephora) }\end{array}$ & S-RNase based GSI ${ }^{\mathrm{a}}$ & $\mathrm{SI}$ & $\begin{array}{l}\text { Overcoming SI to increase } \\
\text { productivity and to facilitate breeding } \\
\text { and crossing with C. arabica }\end{array}$ & Asquini et al. (2011) \\
\hline $\begin{array}{l}\text { Tea } \\
\text { (Camellia sinensis) }\end{array}$ & Unknown (LSI) ${ }^{\mathrm{a}}$ & SI & $\begin{array}{l}\text { - Overcoming SI to develop SC } \\
\text { homozygous lines that facilitate } \\
\text { classical breeding }\end{array}$ & Zhang et al. (2016) \\
\hline $\begin{array}{l}\text { Cocoa } \\
\text { (Theobroma cacao) }\end{array}$ & Unknown (LSI) ${ }^{\mathrm{a}}$ & SI & $\begin{array}{l}\text { - } \quad \text { Prediction of SI/SC genotypes } \\
\text { Selection/development of high- } \\
\text { yield SC plants }\end{array}$ & Lanaud et al. (2017) \\
\hline
\end{tabular}

${ }^{a}$ SI systems where genetic control is unknown and/or whereS-determinants have not yet been identified. SSI, Sporophytic SI; GSI, Gametophytic SI; DSI, sporophytic Diallelic SI; LSI, Late acting SI; LSI.

${ }^{b}$ Predominant expressed phenotype. 
of individual genes one by one in SI networks, SI studies are increasingly adopting a more quantitative approach and also considering environmental influences, phenotypic plasticity, and epigenetics. Nevertheless, our current knowledge of SIenvironment interactions at the molecular level is very sparse and it remains to be seen how it will be applied. In addition, the cell-cell interactions underlying pollen-pistil recognition are also of potential importance because of their parallels to other self/ non-self discrimination processes.

\section{Using Omics and Genome Editing Technologies to Elucidate SI}

Omics technologies, which monitor classes of molecules (e.g., transcripts, proteins, etc.) are particularly well suited to understanding biological systems (Rhee and Mutwil, 2014). Applied to SI, they have the potential to efficiently elucidate the complete network of factors required for SI.

The availability of sequenced and annotated genomes in a broad range of species and accessions (Michael and Jackson, 2013) offers new opportunities to study SI. For instance, genomic sequences enhance the discovery of polymorphisms for refining the genetic and physical maps needed for positional cloning of new SI factors that could then be targeted for breeding. Thus, a GBS (Genotyping By Sequencing) based genome-wide association study identified two loci, $\mathrm{CH} 1$ and $\mathrm{CH} 4$, involved in the cocoa late-acting SI (LSI) system (Lanaud et al., 2017). Both $\mathrm{CH} 1$ and $\mathrm{CH} 4$ were associated with gametic selection, but only $\mathrm{CH} 4$ was associated with the resulting floral abscission. An ortholog of the A. thaliana GEX1 (Gamete Expressed) protein, that is involved in male and female gametophyte development, was significantly associated with fruit set in the cocoa $\mathrm{CH} 4$ genomic region. Stone fruits (Prunus) provide further examples. Two SI modifier genes encoding thioredoxin-family proteins that are probably orthologs have been identified using independent genomics-based mapping strategies in apricot (Muñoz-Sanz et al., 2017a) and sweet cherry (Ono et al., 2018). In addition to identifying SI factors, these studies also provided markers that can readily be used in crop breeding to predict SI/ SC phenotypes.

Transcriptomics may provide functional insights for putative SI factors. RNA-seq analysis has emerged as the preferred technique for transcriptome studies (Wang et al., 2009) and it has played an important role in elucidating the non-self recognition GSI system in Solanaceae and Rosaceae. It was used in Petunia to identify all the pollen specificity SLF genes (Williams et al., 2014; Kubo et al., 2015 ), and up to 24 S-locus Fbox Brothers $(S F B B)$ genes were similarly identified in Malus $\times$ domestica (Pratas et al., 2018).

RNA-seq also has been applied to better understand the molecular basis of SI in tea (Camellia sinensis (L.) Kuntze). SI in tea is not fully characterized but self-pollen rejection has been detected at the ovary consistent with LSI systems. According to Zhang et al. (2016), transcriptome analysis of self/crosspollinated styles permitted identification of a differentially expressed gene (DEG) highly homologous to S-RNase. However, in a similar study, Ma et al. (2018) did not find $S$ -
RNase homologs, but instead identified other DEGs (e.g., aGtype LecRLK). More recently, Seth et al. (2019) constructed coexpression networks to detect transcripts groups with correlated profiles and also identified DEGs in self/crosspollinated pistils. Tissue-specific qRT-PCRs confirmed DEGs in stigma-style and ovary, and support an LSI system that initiates in the style and extends to the ovary with the putative involvement of S-RNase, SRK and SKP genes in self-pollinations. Further research is still needed to clarify genetic control of SI in tea and provide useful tools for breeding.

Contributions to understanding SI from proteomics have been the subject of several reviews (Sankaranarayanan et al., 2013; Fu and Yang, 2014). Here, we highlight recent findings that point to future trends. The first proteomics-like studies of SI were conducted before the term "proteome" was coined and proved decisive in the identification of pistil $S$-determinant proteins in Brassica (Nishio and Hinata, 1980) and Nicotiana (Bredemeijer and Blaas, 1981). Thirty years later, new techniques based on 2 dimensional differential in-gel electrophoresis with or without coupling to MALDI-MS (Matrix Assisted Laser Desorption Ionization-Mass Spectrometry), identified up/down-regulated proteins potentially involved in SI. For instance, analysis of canola stigma proteins revealed the association between $\alpha 2-4$ tubulin levels and the microtubule network following pollen responses (Samuel et al., 2011). Chalivendra et al. (2013) used a tag-based proteomics technique called iTRAQ (Isobaric Tag for Relative and Absolute Quantitation) to follow the expression dynamics of SI factors in pistil development and in UI crosses with $S$. pennellii. This study laid the groundwork for identifying potential SI and UI factors (Bedinger et al., 2017).

The analysis of protein-protein interactions (PPIs) in a cell/ tissue type, has special relevance for SI. These studies can be conducted in vivo using the yeast two hybrid (Y2H) system, or in vitro using affinity purification and pull-down or coimmunoprecipitation (Co-IP) followed by MALDI-TOF-MS (Morsy et al., 2008). For instance, Co-IP/MS of pollen extracts from a transgenic plant over-expressing a GFP-S 2 -SLF1 fusion protein allowed identification of SCF ${ }^{\text {SLF }}$ complex components in Petunia inflata (Zhao et al., 2010) and SSK1 and CUL1 homologs were similarly identified in sweet cherry (Matsumoto et al., 2012). Pull-down assays in Solanum chacoense showed that the pollen eukaryotic translation elongation factor 1Alpha (eEF1A) interacts with $S$-RNase and actin, suggesting that S-RNase may affect the actin cytoskeleton in SI (Soulard et al., 2014). S-RNasebinding pollen proteins also have been detected using $\mathrm{Y} 2 \mathrm{H}$ in sweet cherry and apple (an actin homolog and an ABCF transporter, respectively) (Matsumoto and Tao, 2012; Meng et al., 2014).

In canola, proteomics (including $\mathrm{Y} 2 \mathrm{H}$ ) has facilitated identification of proteins that are down regulated after SI pollinations. Allele-specific recognition of male/female $S$ determinants (SP11/SRK) triggers phosphorylation of the ARC1 E3-ligase that then targets multiple compatibility factors for ubiquitination and degradation. These compatibility factors include Exo70A1, a component of the exocyst complex (Samuel et al., 2009), Glyoxylase I (GLO1), a stigmatic factor that 
detoxifies methylglyoxal (Sankaranarayanan et al., 2015) and phospholipase D1 (PLD1) that produces the necessary phosphatidic acid for exocytosis (Scandola and Samuel, 2019). In another study, Yang et al. (2018) used iTRAQ to study saltinduced SC in canola and found that GLO1 accumulated both in compatible pollinations and in incompatible pollinations after salt solution treatment, and proposed that salt-stress induced GLO1 expression leads to SC response. Thus, proteomics-based identification of proteins associated with salt-induced SC may provide new potential genetic resources for breeding SC lines.

Genome editing will be increasingly helpful for functional testing of putative SI factors. For example, CRISPR/Cas9generated knockout mutants have been used to test the roles of SLF and SSK1 proteins in SI Petunia (Sun and Kao, 2018; Sun et al., 2018) and to demonstrate that a farnesyl pyrophosphatase synthase gene (FPS2) functions in S-RNase-independent UI in Solanum (Qin et al., 2018). As reported above, CRISPR knockout of S-RNase has also been successfully used to obtain SC diploid potato lines for breeding purposes. Other CRISPR-based genome editing tools, such as gene targeting, have not yet been applied to SI, but are also promising.

\section{Environmental Influences on SI: A Quantitative Perspective}

Genetic and evolutionary models of SI typically assume qualitative inheritance. However, a growing body of evidence suggests that SI behaves as a quantitative trait in many species, and may be modulated by environmental conditions (Levin, 2012). Thus, global warming and its expected influence on sexual plant reproduction may become increasingly important. Temperature stress has been shown to affect post-pollinationprezygotic processes (i.e., when pollen-pistil recognition takes place) at several levels including pollen germination and viability, pollen tube growth and dynamics, and ovule viability (Hedhly et al., 2009). For example, temperatures ranging from 32 to $60^{\circ} \mathrm{C}$ can circumvent SI in some genera, though the underlying mechanisms are poorly understood (De Nettancourt, 2001). In Brassicaceae, Yamamoto et al. (2019) recently showed that high temperatures produce $S$-haplotype-dependent stigmatic SI breakdown by disrupting SRK targeting to the plasma membrane. Thus, $S$-haplotypes producing stable levels of SRK protein at elevated temperature, could facilitate production in SI parental lines for F1 hybrid seed production. Understanding how SI responds to elevated temperature may also help to control crop reproduction under a warming environment.

While it is not easy to forecast the effects of human disturbances, including global warming, on plant mating systems, it is reasonable to anticipate negative impacts on pollinators and mate scarcity, factors that could lead to limitations on availability of outcross pollen (Eckert et al., 2010). Indeed, limited availability of bees is already affecting crop management for entomophilous species (Nazzi and Pennacchio, 2014). In this context, reproductive assurance of
SC cultivars would be valuable (Eckert et al., 2010) (see also Pollenizers and Orchard Management). For example, field based studies of SC sunflower show that the absence of pollinators does not affect yield (Astiz et al., 2011).

Pseudo-Self-Compatibility (PSC) systems that display a "leaky" SI response with some level of selfing can be regarded as a plant adaptation to address this challenge. PSC is commonly reflected by production of small fruits with a few small seeds after self-pollination, or by weak SI in older flowers (delayed selfing) (Busch and Schoen, 2008). It has been reported in several SI crops, including almond (Fernández i Martí et al., 2011), sweet cherry (Cachi et al., 2014), pear (Claessen et al., 2019), olive (Saumitou-Laprade et al., 2017), and grasses (Do Canto et al., 2016). Delayed selfing, which is frequently referred to as a "bestof-both-worlds" strategy because it combines the advantages of out-crossing, when possible, and selfing, when needed, has also been reported in several crop families (e.g., Solanaceae, Brassicaceae or Fabaceae) (Goodwillie and Weber, 2017). PSC is quantitative in nature and may be conditioned by the environment. Consequently, it is a variable trait dependent on season and genotype, which limits its usefulness in hybrid breeding and production. However, Do Canto et al. (2016) compiled examples where PSC was useful for hybrid breeding in grasses and proposed its use in distinct schemes for synthetic varieties.

Genetic dissection of PSC may facilitate its practical use and provide tools for fine tuning SI. Although the molecular mechanisms underlying PSC are poorly understood, known causes include, among others, down-regulation of $S$-genes and regulation by modifiers (Busch and Schoen, 2008). Chen et al. (2018) described an example of a modifier gene modulating the SI response. They found that, in pear, phosphatidic acid released by phospholipase D (PLD) may, at least initially, mitigate the toxic effects of the S-RNases in the incompatible pollen tube and delay SI signaling that leads to pollen tube death. In grasses, Do Canto et al. (2016) reviewed evidence supporting that PSC is polygenic in nature and dependent on the environment, and reported correlations between PSC and both $S / Z$-unlinked loci as well as with $S / Z$-haplotypes.

Accumulating evidence supports epigenetic regulation contributing to phenotypic plasticity of SI. In Brassica, Shiba et al. (2006) reported that the dominance relationships between allelic pollen $S$-determinants are controlled by allele-specific DNA methylation of recessive alleles. Tarutani et al. (2010) showed that this is attributed to the presence of an inverted repeat in dominant SP11/SCR alleles that produce a 24nucleotide small RNA homologous to promoter sequences in recessive alleles. Subsequent epigenetic methylation is restricted to the anther tapetum and, therefore, it is not inherited (Fujii and Takayama, 2018). Nasrallah et al. (2007) reported two epigenetic mechanisms that cause SC in Arabidopsis thaliana-lyrata and Capsella rubella-grandiflora interspecific hybrids by producing aberrant SRK transcripts and suppressing SCR expression, respectively. Unlike $S$-locus genes mutations that cause 
irreversible loss of SI, such epigenetic changes are reversible. In almond, Fernández i Martí et al. (2014) recently showed that methylation of cytosine residues in the 5' upstream region of the $S_{f}$-RNase gene leads to the loss of SI.

Epigenetic modifications of SI may therefore be seen as new tools for crop improvement, especially for clonally propagated crops like fruit trees where seed propagation is not used.

\section{SI and Other Self/Non-Self Discrimination Systems}

At the mechanistic level, SI entails cell-cell interactions that discriminate between self/non-self pollen (Nasrallah, 2005). In this sense, SI has parallels with other cell-cell signaling processes like innate immunity and pathogen defense (Sanabria et al., 2008), wounding (Pastuglia et al., 2002), perception of insect feeding (Bonaventure, 2012), and graft-induced stress (Cookson et al., 2014).

There are high-level parallels between plant immunity and SI. For instance, both discriminate against undesirable cells or organisms, and both rely on highly variable receptor-ligand molecules. The recognition receptor is even notably similar in some cases. For example, the Brassica SRK proteins are $S$-domain receptor-like kinases, and similar proteins ( $S$-domain RLKs) have been shown to be up-regulated in response to wounding and pathogen infection and function by recognizing pathogenderived "non-self" ligands (Sanabria et al., 2008; Catanzariti et al., 2015). Moreover, the SCR structure is similar to that of defensin proteins involved in defense against microbial infections in both plants and animals, suggesting a distant evolutionary link between SI and innate immunity in Brassica (Sanabria et al., 2008). There are also remarkable parallels between GSI systems and pathogen recognition. For example, programmed cell death is induced in poppy SI and in the plant immune response and Hugot et al. (2002) suggested that SRNases may have evolved from defense-related RNases.

Plant recognition of phytophagous insects triggers a set of responses to elicit herbivore tolerance and it is thought that discrimination between the feeding behavior of piercing-sucking and chewing insects is a decisive step. The underlying receptorligand interactions have not been fully described, but a lectin receptor kinase1 (LecRK1) in $N$. attenuata was identified as a receptor candidate for perception of chewing by Manduca sexta larvae (Gilardoni et al., 2011). LecRK1 signaling suppresses feeding induced accumulation of salicylic acid, which allows the induction of jasmonic acid-regulated defense responses. LecRK1 is homologous to the Brassica SRK proteins and, like SRKs, contains a predicted N-terminal extracellular region, a single transmembrane domain, and a cytoplasmic serine/ threonine kinase domain. However, they show clear differences in the extracellular binding domains. Potential ligands for LecRK1 are still unknown, but their identification would provide critical information about the mechanisms plants perceive insect feeding (Bonaventure, 2012).

Grafting is commonly used in vegetable and fruit-crops production to favor vigor and stress adaptation. The root system efficiency in grafted plants is directly linked to the compatibility between rootstock and scion and this is highly genotype-dependent. Thus, self/non-self discrimination may also be important for grafting success. For example, Cookson et al. (2014) found a set of receptor kinases differentially expressed in heterografting compared to autografting in grapevine (Vitis spp.) and this suggests some degree of non-self recognition in the hetrografts. Interestingly, these grape receptor kinase genes included homologs of $S$-locus glycoprotein-like gene family. Nevertheless it is important to note that in spite of these general similarities Irisarri et al. (2019) found no correlation between GSI and graft compatibility in the analysis of an apricot (Prunus armeniaca) $\mathrm{F}_{1}$ segregating population.

Thus, perhaps molecular level similarities may be more related to the limited gene repertoire of plants and the physical constraints of signaling than any fundamental similarity between pollen-pistil recognition and other self/non-self recognition. Nevertheless, further studies of SI and other self/non-self discrimination traits might reveal unexpected connections and lead to new applications.

\section{CONCLUDING REMARKS}

Plant reproduction is crucial for crop breeding and production and SI systems are target traits for modulating reproductive behavior. Recent advances in understanding SI have already allowed intra- and interspecific barriers to be overcome and facilitated development of new plant materials (cultivars, hybrids, IL populations, etc.). Moreover, manipulating SI has been helpful to efforts to improve other crop traits such as seedlessness and fruit set. Emerging approaches (omics and genome editing) are also providing additional powerful tools to dissect SI cell-cell recognition mechanisms. Future SI studies will further assist breeders addressing crop production challenges including improvements in plant genetic resources utilization and mitigating effects of global warming on crops.

\section{AUTHOR CONTRIBUTIONS}

CR conceived the original idea. JM-S, EZ, FC-G, BM, and CR contributed to the main conceptual ideas and proof outline. JM-S, BM, and CR wrote the manuscript with support from EZ and FC-G. All authors provided critical feedback and contributed to the final version of the manuscript.

\section{FUNDING}

This work was supported by grants of the Ministerio de Economia y Competitividad del Gobierno de España (AGL2010-19018 and AGL2015-64625-C2-2-R) and the 
Instituto Nacional de Investigaciones Agrarias (RF2011-00020C02-02). We also acknowledge support for publication fee by the CSIC Open Access Publication Support Initiative through its Unit of Information Resources for Research (URICI).

\section{REFERENCES}

Abrol, D. P. (2012). "Historical perspective," in Pollination Biology: Biodiversity Conservation and Agricultural Production. Ed. D. P. Abrol (Heidelberg: Springer), 25-35. doi: 10.1007/978-94-007-1942-2

Asquini, E., Gerdol, M., Gasperini, D., Igic, B., Graziosi, G., and Pallavicini, A. (2011). S-RNase-like sequences in styles of Coffea (Rubiaceae). evidence for SRNase based gametophytic self-incompatibility? Trop. Plant Biol. 4, 237-249. doi: 10.1007/s12042-011-9085-2

Astiz, V., Iriarte, L. A., Flemmer, A., and Hernández, L. F. (2011). Selfcompatibility in modern hybrids of sunflower (Helianthus annuus L.). Fruit set in open and self-pollinated (bag isolated) plants grown in two different locations. Helia 34, 129-138. doi: 10.2298/hel1154129a

Bedinger, P. A., Chetelat, R. T., McClure, B. A., Moyle, L. C., Rose, J. K. C., Stack, S. M., et al. (2011). Insterspecific reproductive barriers in the tomato clade: opportunities to decipher mechanisms of reproductive isolation. Sex Plant Reprod. 24, 171-187. doi: 10.1007/s00497-010-0155-7

Bedinger, P. A., Broz, A. K., Tovar-Mendez, A., and McClure, B. (2017). Pollenpistil interactions and their role in mate selection. Plant Physiol. 173, 79-90. doi: 10.1104/pp.16.01286

Beppu, K., Yamane, H., Yaegaki, H., Yamaguchi, M., Kataoka, I., and Tao, R. (2002). Diversity of $S$-RNase genes and S-haplotypes in Japanese plum (Prunus salicina Lindl.). J. Hortic. Sci. Biotechnol. 77, 658-664. doi: 10.1080/ 14620316.2002.11511553

Beppu, K., Takemoto, Y., Yamane, H., Yaegaki, H., Yamaguchi, M., Kataoka, I., et al. (2003). Determination of $S$-haplotypes in Japanese plum (Prunus salicina Lindl.) cultivars by PCR and cross-pollination tests. J. Hortic. Sci. Biotechnol. 78, 315-318. doi: 10.1080/14620316.2003.11511624

Bernacchi, D., and Tanksley, S. D. (1997). An interspecific backcross of Lycopersicon esculentum $\mathrm{x}$ L. hirsutum: linkage analysis and a QTL study of sexual compatibility factors and floral traits. Genetics 147, 861-877.

Bonaventure, G. (2012). Perception of insect feeding by plants. Plant Biol. 14, 872880. doi: $10.1111 / j .1438-8677.2012 .00650 . x$

Boskovic, R., and Tobutt, K. R. (1996). Correlation of stylar ribonuclease zymograms with incompatibility alleles in sweet cherry. Euphytica 90, 245250. doi: $10.1007 / \mathrm{BF} 00023865$

Bredemeijer, G., and Blaas, J. (1981). S-specific proteins in styles of self-incompatible Nicotiana alata. Theor. Appl. Genet. 59, 185-190. doi: 10.1007/BF00264974

Broothaerts, W., Keulemans, J., and Van Nerum, I. (2004). Self-fertile apple resulting from S-RNase gene silencing. Plant Cell Rep. 22, 497-501. doi: $10.1007 / \mathrm{s} 00299-003-0716-4$

Busch, J. W., and Schoen, D. J. (2008). The evolution of self-incompatibility when mates are limiting. Trends Plant Sci. 13, 128-136. doi: 10.1016/ j.tplants.2008.01.002

Busot, G. Y., McClure, B., Ibarra-Sánchez, C. P., Jiménez-Durán, K., Vázquez-Santana, S., and Cruz-García, F. (2008). Pollination in Nicotiana alata stimulates synthesis and transfer to the stigmatic surface of NaStEP, a vacuolar Kunitz proteinase inhibitor homologue. J. Exp. Bot. 59, 3187-3201. doi: 10.1093/jxb/ern175

Cabrillac, D., Cock, J. M., Dumas, C., and Gaude, T. (2001). The S-locus receptor kinase is inhibited by thioredoxins and activated by pollen coat proteins. Nature 410, 220-223. doi: $10.1038 / 35065626$

Cachi, A. M., and Wünsch, A. (2014). S-genotyping of sweet cherry varieties from Spain and S-locus diversity in Europe. Euphytica 197, 229-236. doi: 10.1007/ s10681-014-1061-0

Cachi, A. M., Hedhly, A., Hormaza, J. I., and Wünsch, A. (2014). Pollen tube growth in the self-compatible sweet cherry genotype, 'Cristobalina', is slowed down after self-pollination. Ann. Appl. Biol. 164, 73-84. doi: 10.1111/aab.12079

Carrera, L., Sanzol, J., Soler, E., Herrero, M., and Hormaza, J. I. (2011). Molecular $S$-genotyping and determination of S-RNase-based incompatibility groups in

\section{ACKNOWLEDGMENTS}

We thank Melody Kroll for editorial assistance and Antonio Monforte for helpful discussions on the manuscript. loquat [Eriobotrya japonica (Thunb.) Lindl.]. Euphytica 181, 267-275. doi: 10.1007/s10681-011-0426-x

Catanzariti, A. M., Lim, G. T. T., and Jones, D. A. (2015). The tomato $I-3$ gene: a novel gene for resistance to Fusarium wilt disease. New Phytol. 207, 106-118. doi: $10.1111 /$ nph. 13348

Chalivendra, S. C., Lopez-Casado, G., Kumar, A., Kassenbrock, A. R., Royer, S., Tovar-Mendez, A., et al. (2013). Developmental onset of reproductive barriers and associated proteome changes in stigma/styles of Solanum pennellii. J. Exp. Bot. 64, 265-279. doi: 10.1093/jxb/ers324

Chen, J., Wang, P., de Graaf, B. H. J., Zhang, H., Jiao, H., Tang, C., et al. (2018). Phosphatidic acid counteracts S-RNase signaling in pollen by stabilizing the actin cytoskeleton. Plant Cell 30, 1023-1039. doi: 10.1105/tpc.18.00021

Chetelat, R. T., and de Verna, J. W. (1991). Expression of unilateral incompatibility in pollen of Lycopersicon penelli is determined by major loci on chromosomes 1, 6 and 10. Theor. Appl. Genet. 82, 704-712. doi: 10.1007/BF00227314

Claessen, H., Keulemans, W., Van de Poel, B., and De Storme, N. (2019). Finding a compatible partner: self-incompatibility in European pear (Pyrus communis); molecular control, genetic determination, and impact on fertilization and fruit set. Front. Plant Sci. 10, 407. doi: 10.3389/fpls.2019.00407

Cookson, S. J., Clemente Moreno, M. J., Hevin, C., Nyamba Mendome, L. Z., Delrot, S., Magnin, N., et al. (2014). Heterografting with nonself rootstocks induces genes involved in stress responses at the graft interface when compared with autografted controls. J. Exp. Bot. 65, 2473-2481. doi: 10.1093/jxb/erul45

Covey, P. A., Kondo, K., Welch, L., Frank, E., Kumar, A., Nuñez, R., et al. (2010). Multiple features that distinguish unilateral incongruity and self-incompatibility in the tomato clade. Plant J. 64, 367-378. doi: 10.1111/j.1365-313X.2010.04340.x

Crane, M. B., and Brown, A. G. (1937). Incompatibility and sterility in the sweet cherry, Prunus avium L. J. Pomol. Hortic. Sci. 15, 86-116. doi: 10.1080/03683621.1938.11513493

Crane, M. B., and Lewis, D. (1942). Genetical studies in pears. III Incompatibility and sterility. J. Genet. 43, 31-49. doi: 10.1007/BF02982745

Currò, S., La Malfa, S., Long, G., Sottile, F., and Gentile, A. (2015). Analysis of Sallele genetic diversity in Sicilian almond germplasm comparing different molecular methods. Plant Breed. 134, 713-718. doi: 10.1111/pbr.12318

De Graaf, B. H. J., Vatovec, S., Juarez-Diaz, J. A., Chai, L., Kooblall, K., Wilkins, K. A., et al. (2012). The Papaver self-incompatibility pollen $S$-determinant, $\operatorname{PrpS}$, functions in Arabidopsis thaliana. Curr. Biol. 22, 154-159. doi: 10.1016/j.cub.2011.12.006

De La Fuente, G. N., Frei, U. K., and Lübberstedt, T. (2013). Accelerating plant breeding. Trends Plant Sci. 18, 667-672. doi: 10.1016/j.tplants.2013.09.001

De Nettancourt, D. (2001). Incompatibility and incongruity in wild and cultivated plants (Berlin Heidelberg: Springer-Verlag).

Do Canto, J., Studer, B., and Lubberstedt, T. (2016). Overcoming selfincompatibility in grasses: a pathway to hybrid breeding. Theor. Appl. Genet. 129, 1815-1829. doi: 10.1007/s00122-016-2775-2

Do Canto, J., Studer, B., Frei, U., and Lübberstedt, T. (2018). Fine mapping a selffertility locus in perennial ryegrass. Theor. Appl. Genet. 131, 817-827. doi: 10.1007/s00122-017-3038-6

Dzidzienyo, D. K., Bryan, G. J., Wilde, G., and Robbins, T. P. (2016). Allelic diversity of S-RNase alleles in diploid potato species. Theor. Appl. Genet. 129, 1985-2001. doi: 10.1007/s00122-016-2754-7

East, E. M., and Park, J. B. (1917). Studies on self-sterility I. the behaviour of selfsterile plants. Genetics 2, 505-609.

East, E. M., and Yarnell, S. H. (1929). Studies on self-sterility VIII. self-sterility allelomorphs. Genetics 14, 455-487.

Eckert, C. G., Kalisz, S., Geber, M. A., Sargent, R., Elle, E., Cheptou, P. O., et al. (2010). Plant mating systems in a changing world. Trends Ecol. Evol. 25, 35-43. doi: 10.1016/j.tree.2009.06.013

Enciso-Rodriguez, F., Manrique-Carpintero, N. C., Nadakuduti, S. S., Buell, C. R., Zarka, D., and Douches, D. (2019). Overcoming self-incompatibility in diploid potato using CRISPR-Cas9. Front. Plant Sci. 10, 376. doi: 10.3389/fpls.2019.00376 
Entani, T., Iwano, M., Shiba, H., Che, F. S., Isogai, A., and Takayama, S. (2003). Comparative analysis of the self-incompatibility $(S-)$ locus region of Prunus mume: identification of a pollen-expressed F-box gene with allelic diversity. Genes Cells 8, 203-213. doi: 10.1046/j.1365-2443.2003.00626.x

Fernández i Martí, A., Howad, W., Tao, R., Alonso Segura, J. M., Arús, P., and Socias i Company, R. (2011). Identification of quantitative trait loci associated with self-compatibility in a Prunus species. Tree Genet. Genomes. 7, 629-639. doi: 10.1007/s11295-010-0362-2

Fernández i Martí, A., Gradziel, T. M., and Socias i Company, R. (2014). Methylation of the $S_{f}$ locus in almond is associated with $S$-RNase loss of function. Plant Mol. Biol. 86, 681-689. doi: 10.1007/s11103-014-0258-x

Foote, H. C. C., Ride, J. P., Franklin-Tong, V. E., Walker, E. A., Lawrence, M. J., and Franklin, F. C. H. (1994). Cloning and expression of a distinctive class of self-incompatibility $(S)$ gene from Papaver rhoeas L. Proc. Natl. Acad. Sci. U.S.A. 91, 2265-2269. doi: 10.1073/pnas.91.6.2265

Franklin-Tong, V., Franklin, F., and De Graaf, B. (2010). Engineering of plants to exhibit SI. Patent No 992 WO/2010/061181 A1. Birmingham, GB.

Fu, Z., and Yang, P. (2014). Proteomics advances in the understanding of pollenpistil interactions. Proteomes 2, 468-484. doi: 10.3390/proteomes2040468

Fujii, S., and Takayama, S. (2018). Multilayered dominance hierarchy in plant selfincompatibility. Plant Reprod. 31, 15-19. doi: 10.1007/s00497-017-0319-9

Fujii, S., Kubo, K., and Takayama, S. (2016). Non-self- and self-recognition models in plant self-incompatibility. Nat. Plants 2, 16130. doi: 10.1038/ nplants.2016.130

Gambetta, G., Gravina, A., Fasiolo, C., Fornero, C., Galiger, S., Inzaurralde, C., et al. (2013). Self-incompatibility, parthenocarpy and reduction of seed presence in'Afourer' mandarin. Sci. Hortic. 164, 183-188. doi: 10.1016/ j.scienta.2013.09.002

García-Valencia, L. E., Bravo-Alberto, C. E., Wu, H.-M., Rodríguez-Sotres, R., Cheung, A. Y., and Cruz-García, F. (2017). SIPP, a novel mitochondrial phosphate carrier, mediates in self-incompatibility. Plant Physiol. 175, 11051120. doi: $10.1104 /$ pp. 16.01884

Gilardoni, P. A., Hettenhausen, C., Baldwin, I. T., and Bonaventure, G. (2011). Nicotiana attenuata LECTIN RECEPTOR KINASE1 suppresses the insectmediated inhibition of induced defense responses during Manduca sexta herbivory. Plant Cell 23, 3512-3532. doi: 10.1105/tpc.111.088229

Gisbert, A. D., Romero, C., Martínez-Calvo, J., Leida, C., Llácer, G., and Badenes, M. L. (2009). Genetic diversity evaluation of a loquat (Eriobotrya japonica (Thunb) Lindl) germplasm collection by SSRs and S-allele fragments. Euphytica 168, 121-134. doi: 10.1007/s10681-009-9901-z

Goldraij, A., Kondo, K., Lee, C. B., Hancock, C. N., Sivaguru, M., VazquezSantana, S., et al. (2006). Compartmentalization of S-RNase and HT-B degradation in self-incompatible Nicotiana. Nature 439, 805-810. doi: 10.1038/nature04491

Goldway, M., Sapir, G., and Stern, A. (2007). "Molecular basis and horticultural application of the gametophytic self-incompatibility system in Rosaceous tree fruits," in Plant Breeding Reviews . Ed. J. Janick (Hoboken, New Jersey: John Wiley \& Sons, Inc), 28215-237.

Goldway, M., Takasaki, T., Sanzol, J., Mota, M., Zisovich, A. H., Stern, R. A., et al. (2009). Renumbering the S-RNase alleles of European pears (Pyrus communis L.) and cloning the S109 RNase allele. Sci. Hortic. 119, 417-422. doi: 10.1016/ j.scienta.2008.08.027

Goodwillie, C., and Weber, J. J. (2017). The best of both worlds? a review of delayed selfing in flowering plants. Am. J. Bot. 105, 641-655. doi: 10.1002/ ajb2.1045

Goring, R. D., Banks, P., Beversdorf, W. D. , and Rothstein, S. J. (1992). Use of the polymerase chain reaction to isolate an $S$-locus glycoprotein cDNA introgressed from Brassica campestris into B. napus ssp. oleifera. Mol. Gen. Genet.,234: 185-192. doi: 10.1007/bf00283838

Gu, Q. Q., Zhang, Q. L., Hu, H. J., Chen, Q. L., and Luo, Z. R. (2009). Identification of self-incompatibility genotypes in some sand pears (Pyrus pyrifolia Nakai) by PCR-RFLP analysis. Agr. Sci. Chin. 8, 154-160. doi: 10.1016/S1671-2927(09) 60022-5

Guerra, M. E., Rodrigo, J., López-Corrales, M., and Wünsch, A. (2009). S-RNase genotyping and incompatibility group assignment by PCR and pollination experiments in Japanese plum. Plant Breed. 128, 304-311. doi: 10.1111/j.14390523.2008.01552.x
Guerra, M. E., López-Corrales, M., and Wünsch, A. (2012). Improved Sgenotyping and new incompatibility groups in Japanese plum. Euphytica 186, 445-452. doi: 10.1007/s10681-012-0636-x

Guichoux, E., Lagache, L., Wagner, S., Chaumeil, P., Léger, P., Lepais, O., et al. (2011). Current trends in microsatellite genotyping. Mol. Ecol. Res. 11, 561591. doi: 10.1111/j.1755-0998.2011.03014.x

Halász, J., Pedryc, A., and Hegedüs, A. (2007a). Origin and dissemination of the pollen-part mutated SC haplotype which confers self-compatibility in apricot (Prunus armeniaca). New Phytol. 2007176, 792-803. doi: 10.1111/j.14698137.2007.02220.x

Halász, J., Hegedüs, A., Szabó, Z., Nyéki, J., and Pedryc, A. (2007b). DNA-based SGenotyping of Japanese plum and pluot cultivars to clarify incompatibility relationships. HortSci 42, 46-50. doi: 10.21273/HORTSCI.42.1.46

Halász, J., Pedryc, A., Ercisli, S., Yilmaz, K. U., and Hegedüs, A. (2010a). Sgenotyping supports the genetic relationships between Turkish and Hungarian apricot germplasm. J. Amer. Soc Hortic. Sci. 135, 410-417. doi: 10.21273/ JASHS.135.5.410

Halász, J., Kurilla, A., and Hegedüs, A. (2014). Preliminary characterization of the self-incompatibility genotypes of European plum (Prunus domestica L.) cultivars. Int. J. Hortic. Sci. 20, 23-26. doi: 10.31421/IJHS/20/3-4/1128

Halázs, J., Fodor, A., Pedryc, A., and Hegedüs, A. (2010b). S-genotyping of Eastern European almond cultivars: identification and characterization of new (S36S39) self-incompatibility ribonuclease alleles. Plant Breed. 129, 227-232. doi: 10.1111/j.1439-0523.2009.01686.x

Hanada, T., Watari, A., Kibe, T., Yamane, H., Wünsch, A., Gradziel, T. M., et al. (2014). Two novel self-compatible S haplotypes in peach (Prunus persica). J. Jpn. Soc Hortic. Sci. 83, 203-213. doi: 10.2503/jjshs1.CH-099

Hancock, N., Kondo, K., Beecher, B., and McClure, B. (2003). The S-locus and unilateral incompatibility. Phil. Trans. R. Soc Lond. 358, 1133-1140. doi: $10.1098 /$ rstb.2003.1284

Hancock, N., Kent, L., and McClure, B. (2005). The $120 \mathrm{kDa}$ glycoprotein is required for $S$-specific pollen rejection in Nicotiana. Plant J. 43, 716-723. doi: 10.1111/j.1365-313X.2005.02490.x

Haussmann, B. I. G., Parzies, H. K., Presterl, T., Sušić, Z., and Miedaner, T. (2004). Plant genetic resources in crop improvement. Plant Genet. Res. 2, 3-21. doi: 10.1079/PGR200430

Hedhly, A., Hormaza, J. I., and Herrero, M. (2009). Global warming and sexual plant reproduction. Trends Plant Sci. 14, 30-36. doi: 10.1016/ j.tplants.2008.11.001

Hegedüs, A., Szabó, Z., Nyéki, J., Halázs, J., and Pedryc, A. (2006). Molecular analysis of S-haplotypes in peach, a self-compatible Prunus species. J. Am. Soc Hortic. Sci. 131, 738-743. doi: 10.21273/JASHS.131.6.738

Herrera, S., Lora, J., Hormaza, J. I., Herrero, M., and Rodrigo, J. (2018). Optimizing production in the new generation of apricot cultivars: selfincompatibility, $S$-RNase allele identification, and incompatibility group assignment. Front. Plant Sci. 9, 527. doi: 10.3389/fpls.2018.00527

Hosaka, K., and Hanneman, R. E. (1998a). Genetics of self-compatibility in a selfcompatible wild diploid potato species Solanum chacoense. 1. detection of an S locus inhibitor (Sli) gene. Euphytica, 99:191-197, . doi: 10.1023/A:1018353613431

Hosaka, K., and Hanneman, R. E. (1998b). Genetics of self-compatibility in a selfcompatible wild diploid potato species Solanum chacoense. 2. Localization of an $S$ locus inhibitor (Sli) gene on the potato genome using DNA markers. Euphytica 103, 265-271. doi: 10.1023/A:1018380725160

Hugot, K., Ponchet, M., Marais, A., Ricci, P., and Galiana, E. (2002). A tobacco Slike RNase inhibits hyphal elongation of plant pathogens. Mol. Plant Mic. Interact. 15, 243-250. doi: 10.1094/MPMI.2002.15.3.243

Igic, B., and Kohn, J. R. (2001). Evolutionary relationships among selfincompatibility RNases. Proc. Natl. Acad. Sci. U.S.A. 98, 13167-13171. doi: $10.1073 /$ pnas. 231386798

Igic, B., Smith, W. A., Robertson, K. A., Schaal, B. A., and Kohn, J. R. (2007). Studies of self-incompatibility in wild tomatoes: I. S-allele diversity in Solanum chilense Dun. (Solanaceae). Heredity 99, 553-561. doi: 10.1038/sj.hdy.6801035 Igic, B., Lande, R., and Kohn, J. R. (2008). Loss of self-incompatibility and its evolutionary consequences. Int. J. Plant Sci. 169, 93-104. doi: 10.1086/523362

Irisarri, P., Zhebentyayeva, T., Errea, P., and Pina, A. (2019). Inheritance of selfand graft-incompatibility traits in an F1 apricot progeny. PloS One 14, e0216371. doi: 10.1371/journal.pone.0216371 
Iwano, M., and Takayama, S. (2012). Self/non-self discrimination in angiosperm selfincompatibility. Curr. Opin. Plant Biol. 15, 78-83. doi: 10.1016/j.pbi.2011.09.003

Iwano, M., Ito, K., Fujii, S., Kakita, M., Asano-Shimosato, H., Igarashi, M., et al. (2015). Calcium signalling mediates self-incompatibility response in the Brassicaceae. Nat. Plants 1, 15128. doi: 10.1038/nplants.2015.128

Jansky, S., Chung, Y., and Kittipadukal, P. (2014). M6: a diploid potato inbred line for use in breeding and genetics research. J. Plant Reg. 8, 195-199. doi: 10.3198/ jpr2013.05.0024crg

Jansky, S. H., Charkowski, A. O., Douches, D. S., Gusmini, G., Richael, C., Bethke, P. C., et al. (2016). Reinventing potato as a diploid inbred line-based crop. Crop Sci. 56, 1412-1422. doi: 10.2135/cropsci2015.12.0740

Jansky, S. (2006). Overcoming hybridization barriers in potato. Plant Breed. 125, 1-12. doi: 10.1111/j.1439-0523.2006.01178.x

Juárez-Díaz, J. A., McClure, B., Vázquez-Santana, S., Guevara-García, A., LeónMejía, P., Márquez-Guzmán, ,. J., et al. (2006). A novel thioredoxin $h$ is secreted in Nicotiana alata and reduces S-RNases in vitro. J. Biol. Chem. 281, 34183424. doi: 10.1074/jbc.M511687200

Jung, H.-J., Jung, H.-J., Ahmed, N. U., Park, J.-I., Kang, K.-K., Hur, Y., et al. (2012). Development of self-compatible $B$. rapa by RNAi-mediated $S$ locus gene silencing. PloS One 7, e49497. doi: 10.1371/journal.pone.0049497

Kakade, V., Dubey, A. K., Sharma, R. M., and Malik, S. K. (2017). Gametophytic self-incompatibility causes seedlessness in 'Kagzi Kalan' lemon (Citrus limon). J. Hortic. Sci. Biotech. 92, 3. doi: 10.1080/14620316.2016.1276415

Kakui, H., Kato, M., Ushijima, K., Kitaguchi, M., Kato, S., and Sassa, H. (2011). Sequence divergence and loss-of-function phenotypes of S locus F-box brothers genes are consistent with non-self recognition by multiple pollen determinants in self-incompatibility of Japanese pear (Pyrus pyrifolia). Plant J. 68, 1028-1038. doi: 10.1111/j.1365-313X.2011.04752.x

Kang, J. G., Nou, I. S., Park, J. I., Yang, K. W., Hwang, I. D., Kim, I. W., et al. (2016). Primer set for assessing combination purity or discriminating genotype of cabbage class-II self-incompatibility factor. Patent No WO/2016/137029 A1. Seoul, KR.

Kaothien-Nakayama, P., Isogai, A., and Takayama, S. (2010). "Self-incompatibility systems in flowering plants," in Plant Developmental Biology - Biotechnological Perspectives Vol I. Eds. E. C. Pua and M. R. Davey (Berlin, Heidelberg: Springer-Verlag), 459-485.

Kempe, K., and Gils, M. (2011). Pollination control strategies for hybrid breeding. Mol. Breed. 27, 417-437. doi: 10.1007/s11032-011-9555-0

Kim, M. H., Shin, D. I., Park, H. S., and Chung, I. K. (2001). In vitro function of SRNase in Lycopersicon peruvianum. Mol. Cells 12, 329-335.

Kim, H. T., Kakui, H., Kotoda, N., Hirata, Y., Koba, T., and Sassa, H. (2009). Determination of partial genomic sequences and development of a CAPS system of the S-RNase gene for the identification of $22 \mathrm{~S}$ haplotypes of apple (Malus $\mathrm{x}$ domestica Borkh.). Mol. Breed. 23, 463-472. doi: 10.1007/s11032-008-9249-4

Kim, K. T., Kim, J. H., Cho, K. H., Park, S. H., Lim, S. H., Yoon, M. K., et al. (2009). Primer set detecting SLG and SRK genotypes of radish self-incompatibility. Patent No 1020090053403 B1. Korea.

Kodad, O., Sánchez, A., Saibo, N., Oliveira, M., and Socias i Company, R. (2008). Identification and characterization of new S-alleles associated with selfincompatibility in almond. Plant Breed. 127, 632-638. doi: 10.1111/j.14390523.2008.01541.x

Kondo, K., Yamamoto, M., Itahashi, R., Sato, T., Egashira, H., Hattori, T., et al. (2002). Insights into the evolution of self-compatibility in Lycopersicon from a study of stylar factors. Plant J. 30, 143-153. doi: 10.1046/j.1365-313x.2002.01275.x

Kučera, V., Chytilová, V., Vyvadilová, M., and Klíma, M. (2006). Hybrid breeding of cauliflower using self-incompatibility and cytoplasmic male sterility. HortSci 33, 148-152. doi: 10.17221/3754-hortsci

Kubo, K., Entani, T., Tanaka, A., Wang, N., Fields, A. M., Hua, Z., et al. (2010). Collaborative non-self recognition system in S-RNase-based selfincompatibility. Science 330, 796-799. doi: 10.1126/science.1195243

Kubo, K., Paape, T., Hatakeyama, M., Entani, T., Takara, A., Kajihara, K., et al. (2015). Gene duplication and genetic exchange drive the evolution of S-RNase based selfincompatibility in Petunia. Nat. Plants 1, 14005. doi: 10.1038/nplants.2014.5

Lachkar, A., Fattouch, S., Ghazouani, T., Halasz, J., Pedryc, A., Hegedüs, A., et al. (2013). Identification of self-(in)compatibility S-alleles and new crossincompatibility groups in Tunisian apricot (Prunus armeniaca L.) cultivars. J. Hortic. Sci. Biotechnol. 88, 497-501. doi: 10.1080/14620316.2013.11512997
Lai, Z., Ma, W., Han, B., Liang, L., Zhang, Y., Hong, G., et al. (2002). An F-box gene linked to the self-incompatibility ( $S$ ) locus of Antirrhinum is expressed specifically in pollen and tapetum. Plant Mol. Biol. 50, 29-42. doi: 10.1023/ A: 1016050018779

Lanaud, C., Fouet, O., Legavre, T., Lopes, U., Sounigo, O., Eyango, M. C., et al. (2017). Deciphering the Theobroma cacao self-incompatibility system: from genomics to diagnostic markers for self-compatibility. J. Exp. Bot. 68, 47754790. doi: $10.1093 / \mathrm{jxb} / \mathrm{erx} 293$

Larsen, B., Ørgaard, M., Toldam-Andersen, T. B., and Pederssen, C. (2016). A high-throughput method for genotyping S-RNase allelesin apple. Mol. Breed. 36, 24. doi: 10.1007/s11032-016-0448-0

Levin, D. A. (2012). Mating system shifts on the trailing edge. Ann. Bot. 109, 613620. doi: $10.1093 / \mathrm{aob} / \mathrm{mcr} 159$

Lewis, D., and Crowe, L. K. (1954). The induction of self-fertility in tree fruits. J. Hortic. Sci. 29, 220-225. doi: 10.1080/00221589.1954.11513813

Lewis, D., and Crowe, L. K. (1958). Unilateral interspecific incompatibility in flowering plants. Heredity 12, 233-256. doi: 10.1038/hdy.1958.26

Li, W., and Chetelat, R. T. (2010). A pollen factor linking inter- and intraspecific pollen rejection in tomato. Science 330, 1827-1830. doi: 10.1126/ science. 1197908

Li, W., and Chetelat, R. T. (2014). The role of a pollen-expressed Cullin 1 protein in gametophytic self-incompatibility in Solanum. Genetics 196, 439-442. doi: 10.1534/genetics.113.158279

Li, W., and Chetelat, R. T. (2015). Unilateral incompatibility gene uil.1 encodes an S-locus F-box protein expressed in pollen of Solanum species. Proc. Natl. Acad. Sci. U. S. A. 112, 4417-4422. doi: 10.1073/pnas. 1423301112

Li, W., Royer, S., and Chetelat, R. T. (2010). Fine mapping of ui6.1, a gametophytic factor controlling pollen-side unilateral incompatibility in interspecific Solanum hybrids. Genetics 185, 1069-1080. doi: 10.1534/genetics.110.116343

Li, P., Miao, H., Ma, Y., Wang, L., Hu, G., Ye, Z., et al. (2015). CrWSKP1, an SKP1like gene, is involved in the self-incompatibility reaction of "Wuzishatangju" (Citrus reticulata Blanco). Int. J. Mol. Sci. 16, 21695-21710. doi: 10.3390/ ijms 160921695

Lim, S. H., Cho, H. J., Lee, S. J., Cho, Y. H., and Kim, B. D. (2002). Identification and classification of $\mathrm{S}$ haplotypes in Raphanus sativus by PCR-RFLP of the $\mathrm{S}$ locus glycoprotein (SLG) gene and the S locus receptor kinase (SRK) gene. Theor. Appl. Genet. 104, 1253-1262. doi: 10.1007/s00122-001-0828-6

Lin, Z., Eaves, D. J., Sanchez-Moran, E., Franklin, F. C., and Franklin-Tong, V. E. (2015). The Papaver rhoeas $S$ determinants confer self-incompatibility to Arabidopsis thaliana in planta. Science 350, 684-687. doi: 10.1126/ science.aad2983

Lisek, A., Kucharska, D., Głowacka, A., and Rozpara, E. (2017). Identification of Shaplotypes of European cultivars of sour cherry. J. Hortic. Sci. Biotech. 92, 484492. doi: 10.1080/14620316.2017.1289071

Liu, W., Chen, X., Liu, G., Liang, Q., He, T., and Jianrong, F. (2007). Interspecific hybridization of Prunus persica with P. armeniaca and P. salicina using embryo rescue. Plant Cell Tissue Org. Cult. 88, 289-299. doi: 10.1007/s11240-007-9201-z

López, M., Vargas, F. J., and Batlle, I. (2006). Self-(in)compatibility almond genotypes: a review. Euphytica 150, 1-16. doi: 10.1007/s10681-005-9009-z

Long, S., Li, M., Han, Z., Wang, K., and Li, T. (2010). Characterization of three new S-alleles and development of an S-allele-specific PCR system for rapidly identifying the S-genotype in apple cultivars. Tree Genet. Genomes. 6, 161168. doi: 10.1007/s11295-009-0237-6

Ma, Q., Chen, C., Zeng, Z., Zou, Z., Li, H., Zhou, Q., et al. (2018). Transcriptomic analysis between self- and cross-pollinated pistils of tea plants (Camellia sinensis). BMC Genomics 19, 289. doi: 10.1186/s12864-018-4674-1

Manzanares, C., Barth, S., Thorogood, D., Byrne, S. L., Yates, S., Czaban, A., et al. (2016). A gene encoding a DUF247 domain protein cosegregates withthe S Self-Incompatibility locus in perennial ryegrass. Mol. Biol. Evol. 33, 870-884. doi: $10.1093 / \mathrm{molbev} / \mathrm{msv} 335$

Matsumoto, Y., and Miyagi, M. (2012). Mapping of a gene conferring alleviation of pollen-pistil incongruity found in an interspecific cross between Cucumis anguria L. and Cucumis melo L. (melon). Sci. Hortic. 146, 81-85. doi: 10.1016/ j.scienta.2012.08.021

Matsumoto, D., and Tao, R. (2012). Isolation of pollen-expressed actin as a candidate protein interacting with S-RNase in Prunus avium L. J. Jpn. Soc Hortic. Sci. 81, 41-47. doi: 10.2503/jjshs1.81.41 
Matsumoto, D., and Tao, R. (2016). Recognition of a wide-range of S-RNases by Slocus F-box like 2, a general-inhibitor candidate in the Prunus-specific SRNase-based self-incompatibility system. Plant Mol. Biol. 91, 459-469. doi: 10.1007/s11103-016-0479-2

Matsumoto, D., Yamane, H., Abe, K., and Tao, R. (2012). Identification of a Skp1like protein interacting with SFB, the pollen $S$ determinant of the gametophytic self-incompatibility in Prunus. Plant Physiol. 159, 1252-1262. doi: 10.1104/ pp.112.197343

McClure, B. A., Haring, V., Ebert, P. R., Anderson, M. A., Simpson, R. J., Sakiyama, F., et al. (1989). Style self-incompatibility gene products of Nicotiana alata are ribonucleases. Nature 342, 955-957. doi: 10.1038/342955a0

McClure, B., Mou, B., Canevascini, S., and Bernatzky, R. (1999). A small asparagine-rich protein required for $S$-allele-specific pollen rejection in Nicotiana. Proc. Natl. Acad. Sci. U.S.A. 96, 13548-13553. doi: 10.1073/ pnas.96.23.13548

McClure, B. A., Cruz-García, F., Beecher, B., and Sulaman, W. (2000). Factors affecting inter- and intra-specific pollen rejection in Nicotiana. Ann. Bot. 85, 113-123. doi: 10.1006/anbo.1999.1061

McClure, B., Cruz-García, F., and Romero, C. (2011). Compatibility and incompatibility in S-RNase-based systems. Ann. Bot. 108, 647-658. doi: $10.1093 / \mathrm{aob} / \mathrm{mcr} 179$

McClure, B. (2009). Darwin's foundation for investigating self-incompatibility and the progress toward a physiological model for S-RNase-based SI. J. Exp. Bot. 60, 1069-1081. doi: 10.1093/jxb/erp024

McClure, B. (2011). Plant self-incompatibility: ancient system becomes a new tool. Curr. Biol. 22, 86-87. doi: 10.1016/j.cub.2011.12.034

Mendler-Drienyovszki, N., Cal, A. J., and Dobránszki, J. (2013). Progress and prospects for interspecific hybridization in buckwheat and the genus Fagopyrum. Biotech. Adv. 31, 1768-1775. doi: 10.1016/j.biotechadv.2013.09.004

Meng, D., Gu, Z., Li, W., Wang, A., Yuan, H., Yang, Q., et al. (2014). Apple MdABCF assists in the transportation of S-RNase into pollen tubes. Plant J. 786, 990-1002. doi: 10.1111/tpj.12524

Miao, H., Qin, Y., Teixeira da Silva, J. A., Ye, Z., and Hu, G. (2011). Cloning and expression analysis of S-RNase homologous gene in Citrus reticulata Blanco cv. Wuzishatangju. Plant Sci. 180, 358-367. doi: 10.1016/j.plantsci.2010.10.012

Michael, T. P., and Jackson, S. (2013). The first 50 plant genomes. Plant Genome 6, 2. doi: 10.3835/plantgenome2013.03.0001in

Morimoto, T., Kitamura, Y., Numaguchi, K., Akagi, T., and Tao, R. (2019). Characterization of post-mating interspecific cross-compatibility in Prunus (Rosaceae). Sci. Hortic. 246, 693-699. doi: 10.1016/j.scienta.2018.11.045

Morsy, M., Gouthu, S., Orchard, S., Thorneycroft, D., Harper, J. F., Mittler, R., et al. (2008). Charting plant interactomes: possibilities and challenges. Trends Plant Sci. 13, 183-191. doi: 10.1016/j.tplants.2008.01.006

Muñoz-Sanz, J. V., Zuriaga, E., Badenes, M. L., and Romero, C. (2017a). A disulfide bond A-like oxidoreductase is a strong candidate gene for self-incompatibility in apricot (Prunus armeniaca) pollen. J. Exp. Bot. 68, 5069. doi: 10.1093/jxb/erx336

Muñoz-Sanz, J. V., Zuriaga, E., López, I., Badenes, M. L., and Romero, C. (2017b). Self-(in)compatibility in apricot germplasm is controlled by two major loci, $S$ and M. BMC Plant Biol. 17, 82. doi: 10.1186/s12870-017-1027-1

Murfett, J. M., Strabala, T. J., Zurek, D. M., Mou, B., Beecher, B., and McClure, B. A. (1996). S-RNase and interspecific pollen rejection in the genus Nicotiana: multiple pollen rejection pathways contribute to UI between self-incompatible and self-compatible species. Plant Cell 8, 943-958. doi: 10.1105/tpc.8.6.943

Nan, J., Xiaofeng, T., Lin, Z., Jingguo, Z., and Hongiu, H. U. (2015). Establishment of self-incompatibility gene cDNA microarray to identify S-genotypes of. Pyrus Pyrifolia. Hortic. Plant J. 1, 121-130. doi: 10.16420/j.issn.2095-9885.2016-0019

Nashima, K., Terakami, S., Nishio, S., Kunihisa, M., Nishitani, C., Saito, T., et al. (2015). S-genotype identification based on allele-specific PCR in Japanese pear. Breed. Sci. 65, 208-215. doi: 10.1270/jsbbs.65.208

Nasrallah, M. E., Liu, P., and Nasrallah, J. B. (2002). Generation of selfincompatible Arabidopsis thaliana by transfer of two $S$ locus genes from $A$. lyrata. Science 297, 247-249. doi: 10.1126/science.1072205

Nasrallah, J. B., Liu, P., Sherman-Broyles, S., Schmidt, R., and Nasrallah, M. E. (2007). Epigenetic mechanisms for breakdown of self-incompatibility in interspecific hybrids. Genetics 175, 1965-1973. doi: 10.1534/genetics.106.069393

Nasrallah, J. B. (2005). Recognition and rejection of self in plant selfincompatibility: comparisons to animal histocompatibility. Trends Immunol. 26, 412-418. doi: 10.1016/j.it.2005.06.005
Nazzi, F., and Pennacchio, F. (2014). Disentangling multiple interactions in the hive ecosystem. Trends Parasitol. 30, 556-561. doi: 10.1016/j.pt.2014.09.006

Nishio, T., and Hinata, K. (1980). Rapid detection of S-glycoproteins of selfincompatible crucifers using Con-A reaction. Euphytica 29, 217-221. doi: 10.1007/BF00025117

Niu, S. C., Huang, J., Xu, Q., Li, P.-X., Yang, H.-J., Zhang, Y.-Q., et al. (2018). Morphological type identification of self-incompatibility in Dendrobium and its phylogenetic evolution pattern. Int. J. Mol. Sci. 19, 2595. doi: 10.3390/ ijms 19092595

Nowak, M. D., Davis, A. P., Anthony, F., and Yoder, A. D. (2011). Expression and trans-specific polymorphism of self- incompatibility RNases in coffea (Rubiaceae). PloS One 6, e21019. doi: 10.1371/journal.pone.0021019

Oikawa, E., Takuno, S., Izumita, A., Sakamoto, K., Hanzawa, H., Kitashiba, H., et al. (2011). Simple and efficient methods for $S$ genotyping and $S$ screening in genus Brassica by dot-blot analysis. Mol. Breed. 28, 1-12. doi: 10.1007/s11032010-9455-8

Okamoto, S., Sato, Y., Sakamoto, K., and Nishio, T. (2004). Distribution of similar self-incompatibility (S) haplotypes in different genera, Raphanus and Brassica. Sex Plant Reprod. 17, 33-39. doi: 10.1007/s00497-004-0211-2

Ono, K., Akagi, T., Morimoto, T., Wünsch, A., and Tao, R. (2018). Genome resequencing of diverse sweet cherry (Prunus avium) individuals reveals a modifier gene mutation conferring pollen-part self-compatibility. Plant Cell Physiol. 59, 1265-1275. doi: 10.1093/pcp/pcy068

Ortega, E., Boskovic, R., Sargent, D. J., and Tobutt, K. R. (2006). Analysis of SRNase alleles of almond (Prunus dulcis): characterization of new sequences, resolution of synonyms and evidence of intragenic recombination. Mol. Gen. Genomics 276, 413-426. doi: 10.1007/s00438-006-0146-4

Park, J.-I., Nou, I.-S., Lee, S. S., Kang, K.-K., and Watanabe, M. (2001). Identification of $S$-genotypes by PCR-RFLP in breeding lines of Brassica. Mol. Cells 12, 227-232.

Pasquer, F., Brey, B., and Frey, J. E. (2008). Identification of cherry incompatibility alleles by microarray. Plant Breed. 127, 413-417. doi: 10.1111/j.14390523.2007.01476.x

Pastuglia, M., Swarup, R., Rocher, A., Saindrenan, P., Roby, D., Dumas, C., et al. (2002). Comparison of the expression patterns of two small gene families of $S$ gene family receptor kinase genes during the defence response in Brassica oleraceae and Arabidopsis thaliana. Gene 282, 215-225. doi: 10.1016/s03781119(01)00821-6

Pembleton, L. W., Shinozuka, H., Wang, J., Spangenberg, G. C., Forster, J. W., and Cogan, N. O. I. (2015). Design of an F1 hybrid breeding strategy for ryegrasses based on selection of self-incompatibility locus-specific alleles. Front. Plant Sci. 6, 764. doi: 10.3389/fpls.2015.00764

Phumichai, C., Mori, M., Kobayashi, A., Kamijima, O., and Hosaka, K. (2005). Toward the development of highly homozygous diploid potato lines using selfcompatibility controlling Sli gene. Genome 48, 977-984. doi: 10.1139/g05-066

Pratas, M. I., Aguiar, B., Vieira, J., Nunes, V., Teixeira, V., Fonseca, N. A., et al. (2018). Inferences on specificity recognition at the Malus $\times$ domestica gametophytic self-incompatibility system. Sci. Rep. 8, 1717. doi: 10.1038/ s41598-018-19820-1

Qiao, H., Wang, H., Zhao, L., Zhou, J., Huang, J., Zhang, Y., et al. (2004). The Fbox protein AhSLF-S 2 physically interacts with S-RNases that may be inhibited by the ubiquitin/26S proteasome pathway of protein degradation during compatible pollination in Antirrhinum. Plant Cell 16, 571-581. doi: 10.1105/ tpc. 017673

Qin, X., Li, W., Liu, Y., Tan, M., Ganal, M., and Chetelat, R. T. (2018). A farnesyl pyrophosphate synthase gene expressed in pollen functions in S-RNaseindependent unilateral incompatibility. Plant J. 93, 417-430. doi: 10.1111/tpj.13796

Quinet, M., Kelecom, S., Raspé, O., and Jacquemart, A.-L. (2014). S-genotype characterization of 13 North Western European pear (Pyrus communis) cultivars. Sci. Hortic. 165, 1-4. doi: 10.1016/j.scienta.2013.10.023

Rahman, M. H. (2005). Resynthesis of Brassica napus L. for self-incompatibility: self incompatibility reaction, inheritance and breeding potential. Plant Breed. 124, 13-19. doi: 10.1111/j.1439-0523.2004.01045.x

Rhee, S. Y., and Mutwil, M. (2014). Towards revealing the functions of all genes in plants. Trends Plant Sci. 19, 212-221. doi: 10.1016/j.tplants.2013.10.006

Riday, H., and Krohn, A. L. (2010). Increasing population hybridity by restricting self-incompatibility alleles in red clover populations. Crop Sci. 50, 853-860. doi: $10.2135 /$ cropsci2009.05.0282 
Ru, S., Main, D., Evans, K., and Peace, C. (2015). Current applications, challenges, and perspectives of marker-assisted seedling selection in Rosaceae tree fruit breeding. Tree Genet. Genomes. 11, 8. doi: 10.1007/s11295-015-0834-5

Sakamoto, K., Kusaba, M., and Nishio, T. (1998). Polymorphism of the S-locus glycoprotein gene $(S L G)$ and the S-locus related gene (SLR1) in Raphanus sativus L. and self-incompatible ornamental plants in the Brassicaceae. Mol. Gen. Genet. 258, 397-403. doi: 10.1007/s004380050747

Samuel, M. A., Chong, Y. T., Haasen, K. E., Aldea-Brydges, M. G., Stone, S. L., and Goring, D. R. (2009). Cellular pathways regulating responses to compatible and self-incompatible pollen in Brassica and Arabidopsis stigmas intersect at Exo70A1, a putative component of the exocyst complex. Plant Cell 21, 2655-2671. doi: 10.1105/tpc. 109.069740

Samuel, M. A., Tang, W., Jamshed, M., Northey, J., Patel, D., Smith, D., et al. (2011). Proteomic analysis of Brassica stigmatic proteins following the selfincompatibility reaction reveals a role for microtubule dynamics during pollen responses. Mol. Cell Proteomics 10, 1-3. doi: 10.1074/mcp.M111.011338

Sanabria, N., Goring, D., Nürnberger, T., and Dubery, I. (2008). Self/nonself perception and recognition mechanisms in plants: a comparison of selfincompatibility and innate immunity. New Phytol. 178, 503-513. doi: 10.1111/j.1469-8137.2008.02403.x

Sankaranarayanan, S., Jamshed, M., and Samuel, M. A. (2013). Proteomics approaches advance our understandingof plant self-incompatibility response. J. Proteome Res. 12, 4717-4726. doi: 10.1021/pr400716r

Sankaranarayanan, S., Jamshed, M., and Samuel, M. A. (2015). Degradation of glyoxalase I in Brassica napus stigma leads to self-incompatibility response. Nat. Plants 1, 15185. doi: 10.1038/nplants.2015.185

Sanwen, H., Chunzhi, Z., Zhen, P., and Mingwang, Y. (2019). Method for overcoming diploid potato self-incompatibility. Patent No CN 109750061 A. China.

Sanzol, J., and Robbins, T. P. (2008). Combined analysis of S-Alleles in European Pear by pollinations and PCR-based S-Genotyping; correlation between SPhenotypes and S-RNase genotypes. J. Am. Soc Hortic. Sci. 133, 213-224. doi: 10.21273/JASHS.133.2.213

Sanzol, J. (2009). Genomic characterization of self-incompatibility ribonucleases (S-RNases) in European pear cultivars and development of PCR detection for 20 alleles. Tree Genet. Genomes. 5, 393-405. doi: 10.1007/s11295-008-0194-5

Sapir, G., Stern, R. A., Eisikowitch, D., and Goldway, M. (2004). Cloning of four new Japanese plum S-alleles and determination of the compatibility between cultivars by PCR analysis. J. Hortic. Sci. Biotechnol. 79, 223-227. doi: 10.1080/ 14620316.2004.11511752

Sapir, G., Stern, R. A., Shafir, S., and Goldway, M. (2007). Multiple introduction of honeybee colonies increases cross-pollination, fruit set and yield of 'Black Diamond' Japanese plum (Prunus salicina Lindl.). J. Hortic. Sci. Biotechnol. 82, 590-596. doi: 10.1080/14620316.2007.11512278

Sapir, G., Stern, R. A., Shafir, S., and Goldway, M. (2008). S-RNase based Sgenotyping of Japanese plum (Prunus salicina Lindl.) and its implication on the assortment of cultivar couples in the orchard. Sci. Hortic. 118, 8-13. doi: 10.1016/j.scienta.2008.05.004

Saumitou-Laprade, P., Vernet, P., Vekemans, X., Billiard, S., Gallina, S., Essalouh, L., et al. (2017). Elucidation of the genetic architecture of self-incompatibility in olive: evolutionary consequences and perspectives for orchard management. Evol. Appl. 10, 867-880. doi: 10.1111/eva.12457

Scandola, S., and Samuel, M. A. (2019). A flower-specific phospholipase D1 is a stigmatic compatibility factor targeted by the self-incompatibility response in Brassica napus. Curr. Biol. 29, 506-512. doi: 10.1016/j.cub.2018.12.037

Schneider, D., Stern, R. A., Eisikowitch, D., and Goldway, M. (2001). Determination of the self-fertilization potency of 'Golden Delicious' apple. J. Hortic. Sci. Biotech. 76, 259-263. doi: 10.1080/14620316.2001.11511360

Schneider, D., Stern, R. A., and Goldway, M. (2005). A comparison between semi and fully compatible apple pollinators grown under suboptimal conditions. HortSci 40, 1280-1282. doi: 10.21273/HORTSCI.40.5.1280

Schoen, D. J., and Chantha, S.-C. (2015). Self-incompatibility system for making Brassicaceae hybrid. Patent No US 2015/0322445 Al. USA.

Schopfer, C. R., Nasrallah, M. E., and Nasrallah, J. B. (1999). The male determinant of self- incompatibility in Brassica. Science 286, 1697-1700. doi: 10.1126/ science.286.5445.1697

Schueler, S., Tusch, A., and Scholz, F. (2006). Comparative analysis of the withinpopulation genetic structure in wild cherry (Prunus avium L.) at the self- incompatibility locus and nuclear microsatellites. Mol. Ecol. 15, 3231-3243. doi: $10.1111 / j .1365-294 X .2006 .03029 . x$

Schuster, M. (2012). Incompatible (S-) genotypes of sweet cherry cultivars (Prunus avium L.). Sci. Hortic. 148, 59-73. doi: 10.1016/j.scienta.2012.09.012

Sehgal, N., and Singh, S. (2018). Progress on deciphering the molecular aspects of cell-to-cell communication in Brassica self-incompatibility response. 3 Biotech. 8, 347. doi: 10.1007/s13205-018-1372-2

Seth, R., Bhandawat, A., Parmar, R., Singh, P., Kumar, S., and Sharma, R. K. (2019). Global transcriptional insights of pollen-pistil interactions commencing self-incompatibility and fertilization in tea [Camellia sinensis (L.) O. Kuntze]. Int. J. Mol. Sci. 20, 539. doi: 10.3390/ijms20030539

Sheick, R., Serra, S., De Franceschi, P., Dondini, L., and Musacchi, S. (2018). Characterization of a novel self-incompatibility allele in Malus and Sgenotyping of select crabapple cultivars. Sci. Hortic. 240, 186-195. doi: 10.1016/j.scienta.2018.05.050

Shiba, H., Hinata, K., Suzuki, A., and Isogai, A. (1995). Breakdown of selfincompatibility in Brassica by the antisense RNA of the SLG gene. Proc. Jpn. Acad. 71, 81-83. doi: 10.2183/pjab.71.81

Shiba, H., Kakizaki, T., Iwano, M., Tarutani, Y., Watanabe, M., Isogai, A., et al. (2006). Dominance relationships between self-incompatibility alleles controlled by DNA methylation. Nat. Genet. 38, 297-299. doi: 10.1038/ng1734

Shin, D. Y., Nou, I. S., Park, J. I., and Lee, I. H. (2012). RNA interference cassette for self-incompatibility factor of Brassica spp. and a vector containing the same. Patent No 1020120001465 B1. Korea.

Shinozuka, H., Cogan, N. O. I., Smith, K. F., Spangenberg, G. C., and Forster, J. W. (2010). Fine-scale comparative genetic and physical mapping supports mapbased cloning strategies for the self-incompatibility loci of perennial ryegrass (Lolium perenne L.). Plant Mol. Biol. 72, 343-355. doi: 10.1007/s11103-0099574-y

Sijacic, P., Wang, X., Skirpan, A. L., Wang, Y., Dowd, P. E., McCubbin, A. G., et al. (2004). Identification of the pollen determinant of S-RNase-mediated selfincompatibility. Nature 429, 302-305. doi: 10.1038/nature02523

Sonneveld, T., Tobutt, K. R., Vaughan, S. P., and Robbins, T. P. (2005). Loss of pollen-S function in two self-compatible selections of Prunus avium is associated with deletion/mutation of an $S$ haplotype-specific F-Box gene. Plant Cell. 17, 37-51. doi: 10.1105/tpc.104.026963

Soulard, J., Boivin, N., Morse, D., and Cappadocia, M. (2014). eEF1A Is an SRNase binding factor in self-incompatible Solanum chacoense. PloS One 9, e90206. doi: 10.1371/journal.pone.0090206

Spagenberg, G. C., Forster, J. W., Cogan, N., Ran, ,. Y., Shinozuka, H., Patron, N., et al. (2014). Manipulation of self-incompatibility in plants. Patent No WO/ 2014/127414 A1. Victoria, AU.

Stern, R. A., Dag, A., Zisovich, A., and Eisikowitch, D. (2001). Sequential introduction of honeybee colonies and doubling their density increases cross-pollination, fruit-set and yield in 'Red Delicious' apple. J. Hortic. Sci. Biotech. 76, 17-23. doi: 10.1080/14620316.2001.11511320

Stern, R. A., Dag, A., Zisovich, A., Shafir, S., and Goldway, M. (2004). Sequential introduction of honeybee colonies increases cross-pollination, fruit-set and yield of 'Spadona' pear (Pyrus communis L.). J. Hortic. Sci. Biotech. 79, 652658. doi: 10.1080/14620316.2004.11511821

Stone, S. L., Arnoldo, M. A., and Goring, D. R. (1999). A breakdown of Brassica self-incompatibility in ARClantisense transgenic plants. Science 286, 17291731. doi: $10.1126 /$ science. 286.5445 .1729

Studer, B., and Asp, T. (2014). $Z$ locus self-incompatibility alleles in Poaceae. Patent No WO/2010/029861 A1. London, GB.

Sun, L., and Kao, ,.T.-h. (2018). CRISPR/Cas9-mediated knockout of PiSSK1 reveals essential role of S-locus F-box protein-containing SCF complexes in recognition of non-self S-RNases during cross-compatible pollination in selfincompatible. Petunia Inflata. Plant Reprod. 31, 129-143. doi: 10.1007/s00497017-0314-1

Sun, L., Williams, J. S., Li, S., Wu, L., Khatri, W. A., Stone, P. G., et al. (2018). Slocus F-box proteins are solely responsible forS-RNase-based selfincompatibility of Petunia pollen. Plant Cell. 30, 2892-2893. doi: 10.1105/ tpc. 18.00615

Takasaki, T., Hatakeyama, K., Suzuki, G., Watanabe, M., Isogai, A., and Hinata, K. (2000). The $S$ receptor kinase determines self-incompatibility in Brassica stigma. Nature 403, 913-916. doi: 10.1038/35002628 
Takayama, S., and Uno, E. (2014). Method for breeding Brassica rapa plant having self-compatibility. Patent No WO/2014/115680 Al. Osaka, JP.

Tantikanjana, T., and Nasrallah, J. B. (2015). Ligand-mediated cis-inhibition of receptor signaling in the self-incompatibility response of the Brassicaceae. Plant Physiol. 169, 1141-1154. doi: 10.1104/pp.15.00572

Tao, R., Yamane, H., Sugiura, A., Murayama, H., Sassa, H., and Mori, H. (1999). Molecular typing of S-alleles through identification, characterization and cDNA cloning for S-RNases in sweet cherry. J. Amer. Soc Hortic. Sci. 124, 224-233. doi: 10.21273/JASHS.124.3.224

Tao, R., Watari, A., Hanada, T., Habu, T., Yaegaki, H., Yamaguchi, M., et al. (2007). Self-compatible peach (Prunus persica) has mutant versions of the S haplotypes found in self-incompatible Prunus species. Plant Mol. Biol. 63, 109123. doi: 10.1007/s11103-006-9076-0

Tarutani, Y., Shiba, H., Iwano, M., Kakizaki, T., Suzuki, G., Watanabe, M., et al. (2010). Trans-acting small RNA determines dominance relationships in Brassica self-incompatibility. Nature 466, 983-987. doi: 10.1038/nature09308

Thorogood, L. D., Armstead, I. P., Turner, L. B., Humphreys, M. O., and Hayward, M. D. (2005). Identification and mode of action of self-compatibility loci in Lolium perenne. Heredity 94, 356-363. doi: 10.1038/sj.hdy.6800582

Tian, L., Miao, W., Liu, J., Fang, Z., Liu, Y., Yang, L., et al. (2013). Identification of S haplotypes in cabbage inbred lines (Brassica oleracea var. capitata L.). Sci. Hortic. 164, 400-408. doi: 10.1016/j.scienta.2013.09.042

Tovar-Méndez, A., Kumar, A., Kondo, K., Ashford, A., Baek, Y. S., Welch, L., et al. (2014). Restoring pistil-side self-incompatibility factors recapitulates an interspecific reproductive barrier between tomato species. Plant J. 77, 727736. doi: $10.1111 /$ tpj. 12424

Tovar-Méndez, A., Lu, L., and McClure, B. (2017). HT proteins contribute to S-RNaseindependent pollen rejection in Solanum. Plant J. 89, 718-729. doi: 10.1111/tpj.13416

Ushijima, K., Sassa, H., Dandekar, A. M., Gradziel, T. M., Tao, R., and Hirano, H. (2003). Structural and transcriptional analysis of the self-incompatibility locus of almond: identification of a pollen expressed F-box gene with haplotypespecific polymorphism. Plant Cell. 15, 771-781. doi: 10.1105/tpc.009290

Ushijima, K., Yamane, H., Watari, A., Kakehi, E., Ikeda, K., Hauck, N. R., et al. (2004). The $S$ haplotype-specific F-box protein gene, $S F B$, is defective in selfcompatible haplotypes of Prunus avium and P. mume. Plant J. 39, 573-586. doi: 10.1111/j.1365-313X.2004.02154.x

Van Tuyl, J. M., and De Jeu, M. J. (2005). "Methods for overcoming interspecific crossing barriers," in Pollen Biotechnology for Crop Production and Improvement. Eds. V. K. Sawhney and K. R. Shivanna (Cambridge, UK: Cambridge University Press), 273-292.

Vardi, A., Levin, I., and Carmi, N. (2008). Induction of seedlessness in citrus: from classical techniques to emerging biotechnological approaches. J. Amer. Soc Hortic. Sci. 133, 117-126. doi: 10.21273/JASHS.133.1.117

Vaughan, S. P., Russell, K., Sargent, D. J., and Tobutt, K. R. (2006). Isolation of Slocus F-box alleles in Prunus avium and their application in a novel method to determine self-incompatibility genotype. Theor. Appl. Genet. 112, 856-866. doi: 10.1007/s00122-005-0187-9

Wang, T., Li, H., Lu, Y., Zhang, J., and Ye, Z. (2007). Identification and distribution of $\mathrm{S}$ haplotypes in Brassica vegetables from China. Sci. Hortic. 112, 271-277. doi: 10.1016/j.scienta.2007.01.012

Wang, Z., Gerstein, M., and Snyder, M. (2009). RNA-Seq: a revolutionary tool for transcriptomics. Nat. Rev. Genet. 10, 57-63. doi: 10.1038/nrg2484

Wang, S., Wang, Q., Zhang, Y., Qie, H., and Wuang, H. (2017). Identification of two new S-RNases and S-genotyping of twenty loquat cultivars [Eriobotrya japonica (Thunb.) Lind.]. Sci. Hortic. 218, 48-55. doi: 10.1016/j.scienta.2017.02.002

Wang, L., Lin, Z., Triviño, M., Nowack, ,. M. K., Franklin-Tong, V. E., and Bosch, M. (2018). Self-incompatibility in Papaver pollen: programmed cell death in an acidic environment. J. Exp. Bot. 70, 2113-2123. doi: 10.1093/jxb/ery406

Wang, Q., Zheng, P., and Zhang, L. (2019). Identification and classification of S haplotypes in radish (Raphanus sativus). Plant Breed. 138, 121-130. doi: 10.1111/pbr.12664

Watanabe, M., Suzuki, G., and Takayama, S. (2008). "Milestones identifying selfincompatibility genes in Brassica species: from old stories to new findings," in Self-incompatibility in flowering plants - evolution, diversity, and mechanisms. Ed. V. E. Franklin-Tong (Berlin Heidelberg: Springer Verlag), 151-172.

Weiss, E. (2015). "Beginnings of fruit growing in the old world" - two generations later. Isr. J. Plant Sci. 62, 75-85. doi: 10.1080/07929978.2015.1007718
Wheeler, M. J., de Graaf, B. H., Hadjiosif, N., Perry, R. M., Poulter, N. S., Osman, $\mathrm{K}$., et al. (2009). Identification of the pollen self-incompatibility determinant in Papaver rhoeas. Nature 459, 992-995. doi: 10.1038/nature08027

Whitford, R., Fleury, D., Reif, J. C., Garcia, M., Okada, T., Korzun, V., et al. (2013). Hybrid breeding in wheat: technologies to improve hybrid wheat seed production. J. Exp. Bot. 64, 5411-5428. doi: 10.1093/jxb/ert333

Wiersma, P. A., Wu, Z., Zhou, L., Hampson, C., and Kappel, F. (2001). Identification of new self-incompatibility alleles in sweet cherry (Prunus avium L.) and clarification of incompatibility groups by PCR and sequencing analysis. Theor. Appl. Genet. 102, 700-708. doi: 10.1007/s001220051700

Wilkins, K. A., Poulter, N. S., and Franklin-Tong, V. E. (2014). Taking one for the team: self-recognition and cell suicide in pollen. J. Exp. Bot. 65, 1331-1342. doi: $10.1093 / \mathrm{jxb} / \mathrm{ert} 468$

Williams, J. S., Der, J. P., de Pamphilis, C. W., and Kao, ,T.-h. (2014). Transcriptome analysis reveals the same 17 S-Locus F-box genes in two haplotypes of the self-incompatibility locus of Petunia inflata. Plant Cell. 26, 2873-2888. doi: $10.1105 /$ tpc.114.126920

Woodcock, T. S. (2012). "Pollination in the Agricultural Landscape," in Best Management Practices for Crop Pollination (Univ. of Guelph: Canadian Pollination Initiative (NSERC-CANPOLIN)), 1-113.

Wu, J., Gu, C., Zhang, S. L., Zhang, S. J., Wu, H. Q., and Heng, W. (2009). Identification of $S$-haplotype specific $S$-RNase and $S F B$ alleles in native Chinese apricot (Prunus armeniaca L.). J. Hortic. Sci. Biotechnol. 84, 645-652. doi: 10.1080/14620316.2009.11512580

Wunsch, A., and Hormaza, J. I. (2004). S-Allele identification by PCR analysis in sweet cherry cultivars. Plant Breed. 123, 327-331. doi: 10.1111/j.1439-0523.2004.00984.x

Xiao, Z., Han, F., Hu, Y., Xue, Y., Fang, Z., Yang, L., et al. (2019). Overcoming cabbage crossingincompatibility by the developmentand application of selfcompatibility-QTL- specific markers and genome-wide background analysis. Front. Plant Sci. 10, 189. doi: 10.3389/fpls.2019.00189

Xin, L., Qiang, L., and Chongwei, L. (2017). Pedigree breeding and wild transplanting method of Dendrobium officinale. Patent No CN 106258956 A. China.

Xue, Y., Carpenter, R., Dickinson, H. G., and Coen, E. S. (1996). Origin of allelic diversity in Antirrhinum S locus RNases. Plant Cell. 8, 805-814. doi: 10.1105/ tpc.8.5.805

Yamamoto, M., Nishimura, K., Kitashiba, H., Sakamoto, W., and Nishio, T. (2019). High temperature causes $S$ haplotype-dependent stigmatic selfincompatibility breakdown in self-incompatible Arabidopsis. J. Exp. Bot. 70, 5745-5751. doi: 10.1093/jxb/erz343

Yamane, H., and Tao, R. (2009). Molecular basis of self-(in) compatibility and current status of S-genotyping in Rosaceous fruit trees. J. Jpn. Soc Hortic. Sci. 78, 137-157. doi: 10.2503/jjshs1.78.137

Yang, Y., Liu, Z., Zhang, T., Zhou, G., Duan, Z., Li, B., et al. (2018). Mechanism of saltinduced self-compatibility dissected by comparative proteomic analysis in Brassica napus L. Int. J. Mol. Sci. 19, 1652. doi: 10.3390/ijms19061652

Yasuda, S., Wada, Y., Kakizaki, T., Tarutani, Y., Miura-Uno, E., Murase, K., et al. (2016). A complex dominance hierarchy is controlled by polymorphism of small RNAs and their targets. Nat. Plants 3, 16206. doi: 10.1038/ nplants.2016.206

Ye, W. J., Qin, Y.H., Ye, Z.X., Teixeira da Silva, J. A., Zhang, L.X., Wu, X. Y., et al. (2009), Seedless mechanism of a new mandarin cultivar 'Wuzishatangju'(Citrus reticulata Blanco). Plant Sci. 177, 19-27. doi: 10.1016/j.plantsci.2009.03.005

Ye, M., Peng, Z., Tang, D., Yang, Z., Li, D., Xu, Y., et al. (2018). Generation of selfcompatible diploid potato by knockout of. S-RNase. Nat. Plants 4, 651-654. doi: 10.1038/s41477-018-0218-6

Zeng, F., and Cheng, B. (2014). Self-(in)compatibility inheritance and allelespecific marker development in yellow mustard (Sinapis alba). Mol. Breed. 33, 187-196. doi: 10.1007/s11032-013-9943-8

Zhang, S. L., and Hiratsuka, S. (2005). Analyses of pollen-tube growth and biological action of $S$-RNase in the style of self-compatible Japanese pear. Sci. Hortic. 104, 169-178. doi: 10.1016/j.scienta.2004.08.017

Zhang, S. L., Huang, S. X., Kitashiba, H., and Nishio, T. (2007). Identification of Shaplotype F-box gene in Japanese plum (Prunus salicina Lindl.). Sex Plant Reprod. 20, 1-8. doi: 10.1007/s00497-006-0037-1

Zhang, X., Ma, C., Tang, J., Tang, W., Tu, J., Shen, J., et al. (2008). Distribution of $S$ haplotypes and its relationship with restorer-maintainers of self- 
incompatibility in cultivated. Brassica napus. Theor. Appl. Genet. 117, 171-179. doi: 10.1007/s00122-008-0763-x

Zhang, L., Chen, X., Chen, X., Zhang, C., Liu, X., Ci, Z., et al. (2008). Identification of self-incompatibility (S-) genotypes of Chinese apricot cultivars. Euphytica 160, 241-248. doi: 10.1007/s10681-007-9544-x

Zhang, S.-W., Huang, G.-X., Ding, F., He, X.-H., and Pan, J.-C. (2012). Mechanism of seedlessness in a new lemon cultivar 'Xiangshui' [Citrus limon (L.) Burm. F.]. Sex Plant Reprod. 25, 337-345. doi: 10.1007/s00497-012-0201-8

Zhang, X., Ma, C., Yin, D., Zhu, W., Gao, C., Zhang, J., et al. (2013). Characterization of $S$ haplotype in a new self-compatible Brassica rapa cultivar Dahuangyoucai. Czech J. Genet. Plant Breed. 49, 157-163. doi: 10.17221/159/2012-CJGPB

Zhang, C.-C., Wang, L.-Y., Wei, K., Wu, L.-Y., Li, H.-L., Zhang, F., et al. (2016). Transcriptome analysis reveals self-incompatibility in the tea plant (Camellia sinensis) might be under gametophytic control. BMC Genomics 17, 359. doi: 10.1186/s12864-016-2703-5

Zhang, Y., Qin, L., Wang, H., Chen, X., and Wang, S. (2017). Identification of S genotypes in loquat (Eriobotrya japonica Lindl.) based on allele specific PCR. Sci. Hortic. 225, 736-742. doi: 10.1016/j.scienta.2017.07.050

Zhao, L., Huang, J., Zhao, Z. H., Li, Q., Sims, T. L., and Xue, Y. B. (2010). The Skp1-like protein SSK1 is required for cross-pollen compatibility in S-RNasebased self-incompatibility. Plant J. 62, 52-63. doi: 10.1111/j.1365-313X. 2010.04123.x
Zhao, Z., Huang, J., Zhao, L., Li, Q., and Xue, Y. (2011). Protein involving SI and cross-compatibility control of phanerogam pollen, coding gene thereof and application. Patent No CN 102234324 A. China.

Zhao, L., Meifeng, G., Huizhen, P., Lulu, C., and Haiou, Q. (2014). Solanum chilense SCF complex CUL1 subunit protein sequence and nucleotide sequence. Patent No CN 103710316 A. China.

Zisovich, A., Stern, R. A., Shafir, S., and Goldway, M. (2005). Fertilisation efficiency of semi and fully-compatible European pear (Pyrus communis) cultivars. J. Hortic. Sci. Biotech. 80, 143-146. doi: 10.1080/14620316.2005.11511906

Conflict of Interest: The authors declare that the research was conducted in the absence of any commercial or financial relationships that could be construed as a potential conflict of interest.

Copyright $\odot 2020$ Muñoz-Sanz, Zuriaga, Cruz-García, McClure and Romero. This is an open-access article distributed under the terms of the Creative Commons Attribution License (CC BY). The use, distribution or reproduction in other forums is permitted, provided the original author(s) and the copyright owner(s) are credited and that the original publication in this journal is cited, in accordance with accepted academic practice. No use, distribution or reproduction is permitted which does not comply with these terms. 